Article

\title{
The Religion of the Ammonites: A Specimen of Levantine Religion from the Iron Age II (ca. 1000-500 BCE)
}

\author{
Craig W. Tyson \\ Department of Humanities, D’Youville College, Buffalo, NY 14201, USA; tysonc@dyc.edu
}

Received: 7 January 2019; Accepted: 26 February 2019; Published: 2 March 2019

\begin{abstract}
In the Iron Age II (ca. 1000-500 BCE), the region around Amman, Jordan, was home to a sociopolitical group known as the Ammonites (literally, "the sons of Ammon"). This paper investigates the religious traditions of the Ammonites through an analysis of the extant archaeological and textual sources. The analysis leads to the conclusion that the religious tradition of the Ammonites is a specimen of the broader religious tradition of the Iron Age II Levant. One distinguishing feature of Ammonite religion is the state god Milkom, whose name is probably an epithet for the god 'El, and who appears to be represented in a tradition of stone sculptures that have been found in the vicinity of Amman. The rest of the non-physical realm was understood to be inhabited by gods, goddesses, a variety of other non-human beings, and dead ancestors. Also visible in the extant evidence is a blending of local and foreign elements, especially those from Mesopotamia. Unique in this respect is the probable temple to the moon-god at Rujm al-Kursi, which most likely reflects a local tradition of lunar worship influenced by the iconography of the Mesopotamian moon-god Sîn.
\end{abstract}

Keywords: Ammon; sons of Ammon; Ammonite; gods; Milkom; iconography; Jordan; Iron Age

\section{Introduction}

Centered on the region around the modern city of Amman, Jordan (Figure 1), the tribally organized, agropastoralist society of the Ammonites (literally, "the sons of Ammon") flourished during the Iron Age II (ca. 1000-500 BCE), and especially in the latter half of this period. Like other aspects of its culture, Ammonite religion shares much in common with the other cultures of the ancient Levant (Judah, Israel, Aram, Phoenicia, Philistia, Moab, and Edom). These shared traits include a state god, a variety of other gods and goddesses, a special place for the ancestors, public and private cultic areas, and indicators of adaptations from regional peers and from the major political powers of the day located in Mesopotamia and Egypt. While Ammonite religion shares much with the surrounding cultures, there are also unique features. One distinguishing feature of Ammonite religion is the state god Milkom, whose name is probably an epithet for the god 'El, and who appears to be represented in a tradition of stone sculptures that have been found in the vicinity of Amman. Also unique is the probable temple to the moon-god at Rujm al-Kursi, which most likely reflects a local tradition of lunar worship influenced by the iconography of the Mesopotamian moon-god Sîn. 


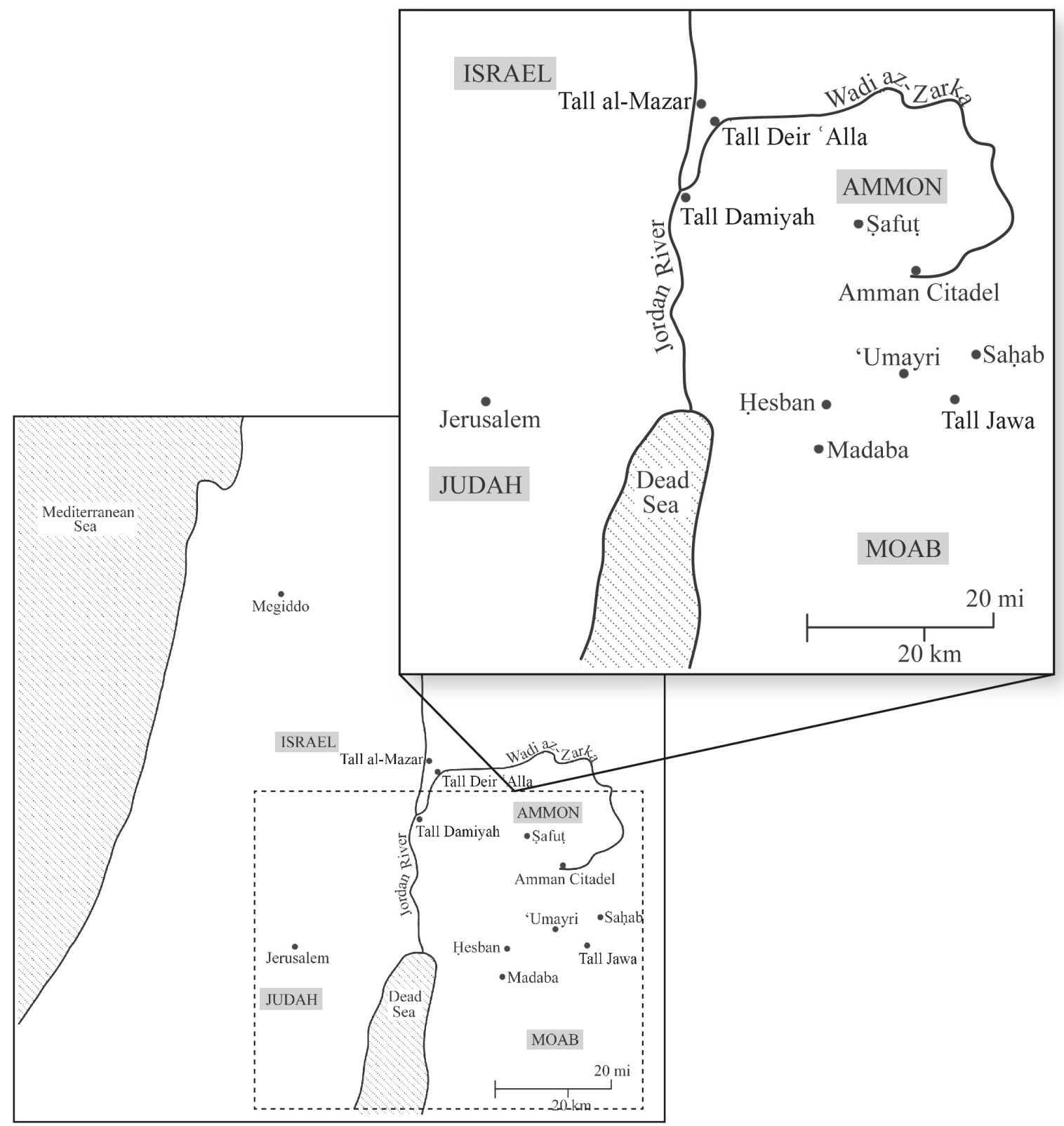

Figure 1. Map of Iron Age II Ammon.

\section{Defining the Area of Inquiry}

As is well-known, religion is a notoriously slippery term, and it is understood in disparate ways by different scholars. It is therefore useful to establish a working definition. For this investigation, I will use the broad collection of human behaviors and ideas that evolutionary models of religion are often used to explain, as proposed by Boyer and Bergstrom (2008, p. 112):

- mental representations of nonphysical agents, including ghosts, ancestors, spirits, gods, ghouls, witches, etc., and beliefs about the existence and features of these agents;

- artifacts associated with those mental representations, such as statues, amulets, or other visual representations or symbols;

- $\quad$ ritual practices associated with stipulated nonphysical agents;

- moral intuitions as well as explicit moral understandings that people in a particular group connect to nonphysical agency; 
- $\quad$ specific forms of experience intended to either bring about some proximity to nonphysical agents or communicate with them;

- ethnic affiliation and coalitional processes linked to nonphysical agents.

The nature of the evidence for Ammonite religion is not robust enough to say something about each of these categories. For example, there is essentially no evidence for moral intuition connected to nonphysical agency. On the other hand, there is material evidence for rituals, but such evidence often only allows for the reconstruction of the basic outlines of rituals.

\section{Primary and Secondary Sources for Ammonite Religion}

A few words on the sources available for this study will be useful to orient the reader. The study of the ancient past is dependent on the available archaeological and textual sources. For the Ammonites in particular, two primary sources, and one secondary source exist. The primary sources are materials unearthed through archaeological excavations (architecture, pottery, and other manmade items) and inscriptions (which are a special subset of archaeologically excavated material). The secondary source for the Ammonites is the Hebrew Bible/Old Testament, whose texts were not written contemporaneously with the events that they purport to record. There are a few possible exceptions to this (e.g., the book of Jeremiah) that I will note where relevant. For the most part, it will be the archaeological and inscriptional material that will serve as the basis for the discussion, with biblical texts brought in and evaluated where relevant.

\section{Nonphysical Agents}

\subsection{Milkom and 'El}

The main sources of information about nonphysical beings in Ammon are a small corpus of short inscriptions, various types of images recovered in the archaeology (statues, figurines, and iconography on seals), and several texts from the Hebrew Bible. While the evidence is incomplete, it provides some clues about the gods and goddesses known among the Ammonites. Of these, Milkom and 'El are of particular importance.

The earliest reference to an Ammonite deity appears to be on the Amman Citadel Inscription (CAI, no. 59), ${ }^{1}$ which has been dated paleographically between the mid-ninth and early eighth century BCE (CAI, no. 59). ${ }^{2}$ The block of limestone on which the inscription was incised was reworked for use in a later building, leaving eight lines of partially preserved text. The exact function of this inscription is debated; however, its composition on stone and the fact that it was discovered in the capital of the Ammonites, suggests that it was a monument commemorating a building project or other accomplishments of the king. The beginning of the first extant word on the inscription is missing, but most agree that it should be restored as $[\mathrm{m}] \mathrm{lkm}$ and vocalized as the name of the deity Milkom (CAI, no. 59), giving us our earliest attestation of this deity name in Ammon. This is significant for two reasons. First, because monumental inscriptions are regularly associated with kings in the Iron Age Levant, and the deities mentioned on them are understood to support the king in his activities—especially military and building activities (Green 2010). Second, because later texts from the Hebrew Bible identify Milkom as "the god of the Ammonites" (1 Kings 11:5, 33; 2 Kings 23:13),

\footnotetext{
$C A I=$ Aufrecht, Walter E. Forthcoming. A Corpus of Ammonite Inscriptions, 2nd ed. University Park: Eisenbrauns.

In keeping with the principle that our understanding of the ancient world should be built on inscriptions and other artifacts recovered from known archaeological contexts rather than items purchased on the market (Rollston 2004; 2010, pp. 137-44), all inscriptions discussed in the main body of the article are provenanced. Non-provenanced inscriptions are noted in the footnotes where relevant, and the symbol $\varnothing$ is placed before the reference to flag their non-provenanced status.
} 
a role that is parallel in the mind of the biblical author to the Israelite and Judean state ${ }^{3}$ god Yahweh, as well as the gods of other political groups in the region.

Milkom also appears as part of personal names on two Ammonite inscriptions. As with names in other Semitic languages, Ammonite names are often constructed from a deity name and a predicate (e.g., Abdallah, "Servant of Allah"). The first is a seal found at Tall al-'Umayri, a site just to the southwest of the modern city Amman. Dated to about $600 \mathrm{BCE}$, the seal reads, "(Belonging) to Milkom' or, servant of Ba alyašu'" (CAI, no. 129). Milkom' or, whose name means "Milkom is light," was apparently part of the court of king Ba' alyašu', who is regularly identified with the Ammonite king Baalis mentioned in the biblical book of Jeremiah 40:14 (Becking 1993; Herr 1985, p. 172). The second name, Milkomyat, appears in a list of names of unknown purpose on an ostracon (ink on pottery) from Tall al-Mazar, and is dated to the fifth century BCE (CAI, no. 147). ${ }^{4}$ The name, Milkomyat, means something like, "May Milkom come." While the sample is tiny, the use of Milkom in personal names at the end of the Iron Age II illustrates the ongoing place of Milkom amongst the Ammonites.

As mentioned above, the Hebrew Bible speaks of the role of Milkom among the Ammonites. Written in ancient Israel and Judah, and then subsequently compiled in Judah, the biblical texts portray the gods of other people as a danger to the people of Israel and Judah, a snare that will lure them away from the proper worship of their god Yahweh. Milkom is unambiguously attested three times in the Hebrew text (1 Kings 11:5, 33; 2 Kings 23:13). ${ }^{5}$ In each occurrence, Milkom of the Ammonites is part of a list of non-Israelite deities whom king Solomon is said to have followed, an act described by the biblical author as doing "what was evil in the sight of Yahweh" (1 Kings 11:6). The illicit nature of Solomon's attention to the deities of the surrounding peoples has to do with the exclusive nature of the relationship between Yahweh and the Israelites (Exodus 20:1-3). Following after gods other than Yahweh is presented as a perennial problem for the Israelites in much of the Hebrew Bible, but perhaps nowhere more systematically than in the Deuteronomistic History (Deuteronomy-2 Kings). There, the worship of Yahweh only is connected closely with the only true place to worship him, Jerusalem.

In several other biblical texts, there was confusion in antiquity as to what the consonant sequence $m l k m$ represented. The translators of the Hebrew Bible into Greek (often referred to as the Septuagint or LXX) struggled with the meaning of the Hebrew mlkm in 2 Samuel 12:30; 1 Chronicles 20:2; Amos 1:15; Jeremiah 49:1, 3 [Greek 30:17, 19]; Zephaniah 1:5. This series of Hebrew consonants is variously rendered into Greek as melchom, melchol, molchom, molchol, ${ }^{6}$ or translated as basileus, "king." Should this word be read as "their king" (the final $-m$ representing the third masculine plural suffix attached to the word for king) or as the name of the Ammonite god?

In 2 Samuel 12:26-31, David's army captured Rabbah, the capital city of the Ammonites. Once the city was captured, the text states, "[David] took the crown of $m l k m$ from his head-its weight was a talent of gold and it had a precious stone-and it was put on the head of David. And he brought out a great amount of the spoil of the city" (2 Samuel 12:30). The key word in Hebrew is mlkm, which the MT reads as malkām, "their king." However, the Greek translation of 2 Samuel 12:30 (paralleled in

3 The choice of the designation "state god" is a matter of convenience. Several other possibilities, such as "national god," "dynastic god," or "royal god", are possible alternatives. Each comes with its own problems of meaning.

4 Milkom appears on several non-provenanced inscriptions, either as part of a name (ØСAI, nos. 1b, 127, 136), or in a blessing in the form of, "so-and-so, blessed of Milkom" (ØСAI, nos. 55, 57).

5 The traditional Hebrew text that is the basis for all modern translations is often called the Masoretic Text, abbreviated as MT. When it was originally written, Hebrew (as with other Semitic languages) was written with consonants only and did not graphically represent vowels. In 1 Kings 11:7, there is what appears to be a scribal mistake. In the same chapter and context as two other references to Milkom (vv. 5, 33), the MT says that Solomon built a $b \bar{a} m \hat{a}$, "high place" for Chemosh, the detestable (god) of Moab, and for molek the detestable (god) of the Ammonites. The context alone suggest that this was a simple scribal error, the consonants mlk being very close to the consonants for Milkom's name, mlkm. The Lucianic Greek translation of this verse represents it as melchol, which might be a confusion of M and L in Greek uncial script (on which, see the following note). In addition, the rest of the biblical evidence on molek (whether a god or as a designation of a sacrifice) is not connected with Milkom, nor with the Ammonites (Heider 1999). It thus seems most likely that this was a simple mistake on the part of the copyist.

6 On the confusion of M and L in Greek uncial script, see (Puech 1999, p. 575). 
1 Chronicles 20:2) has melchol tou basileōs autōn "Melchol their king." It is thus difficult to determine whether the crown was taken off the human king of the Ammonites, or whether the crown was taken off of the head of a statue of Milkom. Involving the gods of enemy peoples in warfare was a common phenomenon in the ancient Near East, so David's despoliation of Milkom's crown would not be out of the ordinary in terms of military practice. Also, the weight of the crown is stated as one talent, which is about $75 \mathrm{lbs}$, suggesting that a statue might be in view here (Driver 1913, p. 294; Knoppers 2004, p. 734). Werse is correct to point out; however, that using the weight of the crown as an argument for it being on a statue runs square in the face of the following words that it was placed upon David's head (Werse 2018, p. 511). Other manuscript evidence also supports the MT, indicating that the Greek has added a reference to Milkom, while also preserving the reference to "their king." In this instance, the shorter reading that takes this as a simple reference to the Ammonite king is probably the best (Werse 2018, p. 511).

There are some issues with understanding the consonant sequence $m l k m$ in the biblical prophetic books as well. Some Greek manuscripts of Amos take the occurrence of $m l k m$ in Amos 1:15 to represent the Ammonite deity Milkom; however, in this case, the majority of the manuscript evidence indicates that "their king" is the proper translation (Werse 2018, pp. 512-13, n. 30). Likewise, the wider context of this verse has a focus on human rulers, making the reading of Milkom less likely (Paul 1991, pp. 70-71; Puech 1977; Werse 2018, pp. 512-13, n. 30).

In Jeremiah 49:1, 3 (Greek 30:17, 19) the Greek renders mlkm as melchom, while the MT reads mlkm as "their king." As part of a set of oracles aimed at the nations surrounding Israel and Judah, Jeremiah 49:1-6 accuses the Ammonites of wrong doing against Israel (v. 1) and hubris (v. 4), and subsequently issues a prediction of judgment (vv. 2-3,5), and a final promise of restoration by the Israelite god Yahweh (v. 6). Since each of the oracles in this series are constructed in the same form, the textual problem in vv. 1 and 3 is best resolved by considering the parallel oracle against Moab in Jeremiah 48 . There, in v. 7, the judgment is on the Moabite god Chemosh, who will "go out into exile, his priests and officials together." The similar wording in Jeremiah 49:3, "For mlkm will go into exile, his priests and his officials together" argues strongly in favor of reading Milkom rather than "their king" in 49:1 and 3 (Werse 2018, p. 512). ${ }^{7}$

Finally, in Zephaniah 1:5, while the MT and some Greek manuscripts read "their king," the Lucianic recension of the Greek translates mlkm as melchom, a reading also supported by the Syriac and the Latin Vulgate. Here, the key is to recognize the clear focus on illicit worship that makes "Milkom" the most likely translation. In this oracle of judgment on Judah, illicit religious practices are the target in 1:4-6. The worship of the god Ba'al, astral worship ("the host of heaven"), and oath taking in the name of the Judean god Yahweh, as well as the being indicated by $m l k m$, are all condemned, along with a generalized lack of not following Yahweh. The act of swearing or oath-taking mentioned in v. 5 is a particularly important piece of evidence here, as the Hebrew Bible always identifies the entity that is sworn by as a deity (Werse 2018, p. 506). Thus, in this case, the manuscript evidence and the context support reading "Milkom" in Zephaniah 1:5.

The biblical passages that mention Milkom are not a significant source of evidence about Milkom, but they do regularly understand him as the god of the Ammonites, parallel in the mind of the writers to Chemosh of Moab and Astarte of Sidon. The epigraphic and biblical evidence thus overlap in the image of Milkom as a state god of the Ammonites. The earliest evidence (the Amman Citadel Inscription) comes from the late ninth to eighth centuries BCE, and the two seals and biblical texts provide data on the later end, dating to the seventh and sixth centuries BCE. What is interesting is that despite the connection between Milkom and the state, the rest of the Ammonite epigraphic record shows a surprising trend in the Ammonite onomasticon, where the deity name 'El is much

7 On the practice of deporting cult images, see (Cogan 1974, pp. 9-21). 
more common than the theophoric element than Milkom. ${ }^{8}$ Additionally, the names of several known Ammonite kings are 'El names, ${ }^{9}$ while none contain Milkom.

The preponderance of 'El names in the onomasticon appears to parallel a trend in the iconography. A collection of nine male sculptures carved from stone (Abou Assaf 1980, nos. I, III-VII, XVIII, XIX, XX; Amr 1990, no. 1), as well as a small clay head (Daviau and Dion 1994) have been discovered in the region around Amman, and they date from the eighth to sixth centuries BCE. While varying somewhat in their appearances, they all wear an atef crown, which has its origins in Egypt, but has a long history in the iconography of the Levant (Figure 2). In its application in the Levant, and in Ammon particularly, the atef crown is worn by a deity-including 'El-who is typically in support of royal power (Burnett 2016, pp. 63-65; Daviau and Dion 1994, pp. 160-61). In combination with the number of 'El names, all of the items in this corpus most likely represent an important-perhaps chief-god of the Ammonites, who is associated with royal power (Burnett 2009, pp. 153-58; Burnett 2016, p. 65). In the Ammonite context, this god is most likely 'El (Daviau and Dion 1994, pp. 164). ${ }^{10}$

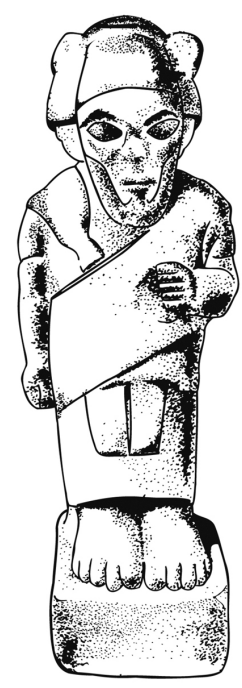

Figure 2. Atef crowned statuette from the Amman Citadel. Drawing by Thomas Norman.

Identifying 'El as an Ammonite state god based on the epigraphic and iconographic evidence creates tension with the biblical texts that identify Milkom as the god of the Ammonites. There are several possible ways of dealing with this tension. First, it is entirely possible that 'El and Milkom are two separate gods, with Milkom perhaps related to kingship. However, this solution has not been the one that scholars have often pursued. The patterns in the epigraphic, iconographic, and biblical record seem to call for something more. One main solution has been to argue that Milkom was indeed the god of the Ammonites, the state god or head of the pantheon, who was or had been identified with 'El over a period of time, as seems to be the case with Yahweh in Israel and Judah (Lemaire 1994,

8 For a list and discussion of names from provenanced Ammonite inscriptions and non-provenanced inscriptions that are plausibly Ammonite, see (Aufrecht 1999, pp. 156-58). One other possible Milkom name from the nearby site of Deir 'Alla appears on a worn seal that may or may not be Ammonite (CSAJ, pp. 404-5, Deir 'Alla 27).

9 King Pado'il appears in several texts from the Neo-Assyrian Empire, which mention him paying tribute, or giving gifts and supplies to the Assyrian king (Grayson and Novotny 2012, p. 175, no. 22 ii 55; Leichty 2011, p. 23, no. 1 v 62; Postgate 1974, p. 337, ADD 1110+ A.i. $\left.5^{\prime}-6^{\prime}\right)$. See also the non-provenanced seal in ØCAI, no. 13.

10 Abou Assaf also argues that these represent the chief god of the Ammonites, but identifies him as Milkom (Abou Assaf 1980, p. 78). 'Amr argues that they represent humans (Amr 1990, pp. 116-17), but he assumes an unmediated Egyptian influence, which seems unlikely in the eighth-sixth centuries BCE considering Egypt's relative inactivity in the Levant, except in the coastal areas at the end of the seventh and beginning of the sixth century. Daviau and Dion's argument assumes a more likely diffusion of the artistic motifs mediated by the coastal cultures. Furthermore, these heads may be seen as part of a sequence, beginning in the ninth century BCE with the clay head from Tall Jawa that Daviau and Dion publish (Daviau and Dion 1994, p. 163), and continuing down into the seventh century (Abou Assaf 1980, p. 71). 
p. 143). ${ }^{11}$ This proposal, based on the reconstructed history of religion in ancient Israel and Judah, is dependent on the assumption that parallel processes operated in Israel and Judah on the one hand, and in Ammon on the other. While it is certainly possible that parallel processes worked out in both areas, the extant evidence for the two adjacent areas is different. In Judah and Israel, the biblical and epigraphic material demonstrate a distinct preference for personal names using the theophoric element Yahweh, as well as the use of Yahweh's name in blessings and salutations (Tigay 1987). Likewise, biblical texts such as Exodus 6:2-3 and others point to Yahweh's identification with 'El, at least in the minds of some biblical authors (Smith 2002, pp. 32-43). The extant material from Ammon, consisting largely of names, does not fit this pattern strongly, and hence does not demonstrate that such a merger is likely (Cornell 2015). ${ }^{12}$

The other main proposal argues that 'El was the head of the Ammonite pantheon and that Milkom was an epithet, or a way of speaking of 'El (Burnett 2009; Daviau and Dion 1994, p. 164 n. 17; Tigay 1987, pp. 171, 187, n. 66). This takes seriously the reality that 'El names far outnumber Milkom names in the Ammonite onomasticon, as well as the representations of ' $\mathrm{El}$ in Ammonite iconography. It also lays emphasis on the linguistic connection between Milkom's name $(\mathrm{mlkm})$ and the consonants for the Northwest Semitic root $m l k$, on which the verb for ruling and the noun for king (melek) are built. Milkom's name is most likely built on this root and thus has something to do with ruling, a proposal that is supported by the appearance of similar god names in earlier Semitic inscriptions from Ugarit (on the coast of Syria) and elsewhere (Puech 1999, p. 575). Burnett's formulation of this position is probably the best when he says that Milkom is a "title distinct to the Ammonite form of 'El in his capacity as a royal god" (Burnett 2009, p. 161). While material uncovered in future archaeological excavations might necessitate a reconsideration of this position, the current state of the evidence favors the view that Milkom is a title or epithet of an Ammonite state god 'El. In keeping with many of the state gods of the Levant, he was in all likelihood understood as a weather god (Hübner 1992, p. 262).

\subsection{Ba'al}

The god $\mathrm{Ba}$ al is known from three provenanced Ammonite inscriptions. ${ }^{13}$ The Amman Theatre Inscription (CAI, no. 58) is a small basalt fragment with two broken lines of text dated to around 600 BCE. It was part of a longer inscription, perhaps meant for display. The first partial line of text has the name Ba' al, followed by what is probably the verb, "I will build." Given the tiny amount of preserved text, it is not possible to say much about the inscription other than to discuss the individual words. It does seem significant though that the name Ba' al appears on the type of inscription (an inscription on stone that was likely much bigger) that would normally record kingly deeds.

$C A I$, no. 129 , which was discussed above $(\S 4.1)$, is a seal found at Tall al-'Umayri that reads, "(Belonging) to Milkom' or, servant of Ba'alyašu'." The name of the person served-Ba' alyašu'-is most likely the king of the Ammonites (cf. Jeremiah 40:14). His name means, "Ba' al is salvation" or "Ba' al has saved." That a king would have a Ba'al name does not mean that Ba' al was necessarily closely connected to kingship in Ammon. On the other hand, someone among the Ammonite elite saw Ba' al to be important enough to invoke him in their child's name. The last provenanced inscription that includes the name Ba' al again comes from Tall al-'Umayri, this time in the form of a seal impression on a jar rim (CAI, no. 173). The script on the inscription is likely Aramaic and dated to the late sixth or early fifth century BCE. The first line has the name $\mathrm{Ba}$ 'al and the second line only contains the first two letters of a word. It is possible that the two lines should be taken together as one name breaking

11 On this phenomenon in Judah and Israel see (Smith 2001, pp. 47-53).

12 Cornell's study also raises important methodological questions about the priority of the textual material from Ugarit (14th-13th c. BCE) for reconstructing Israelite and Judean religion. If the Ammonite material is prioritized as the closest analogue in time and space to Israel and Judah, the pattern for god mergers through which to view the history of Yahweh is not as strong (Cornell 2015).

13 This deity name also occurs in the following non-provenanced inscriptions that are possibly Ammonite: ØCAI, nos. 1, 9b, $38 a, 59 b, 175,212$. 
over two lines, but whatever the case, the Ba' al part is clear. Assuming it is part of a personal name, it provides one more bit of evidence for the worship of $\mathrm{Ba}$ 'al in the region.

It is not surprising to find references to Ba'al in Ammonite inscriptions, as he was, in his various local permutations, well-known through much of the ancient Near East beginning in the third millennium BCE and well down into the first millennium. In some cases, the word $b a^{\prime} a l$, which means "lord" or "owner," seems to have been used as an epithet for other deities, while in others it is clearly a proper name of a god (Herrmann 1999, p. 132). The Ugaritic texts from Ras Shamra on the coast of Syria (14th-13th c. BCE) provide the most robust portrayals of Ba' al and his various roles in kingship, fertility of the land via his control of the weather, and control over the sea, which was so important to sailors (Herrmann 1999, pp. 132-36). The significant friction on display in the Bible between the followers of Yahweh and the followers of Ba' al highlights Ba' al's role in nationalist politics and in the arena of fertility (see especially 1 Kings 17-19). It would thus not be surprising to find that Ammonites and their rulers included $\mathrm{Ba}$ 'al among the gods that they looked to for protection and sustenance. Ba' alyašu"s name suggests such a line of thinking, though it must also be admitted that the "salvation" included in his name most likely relates to his birth rather than anything to do with kingship. Whatever the precise role Ba' al was understood to have among the Ammonites, the few occurrences of his name secure him a spot in the Ammonite pantheon and further demonstrate Ammonite participation in the much more broadly attested patterns of religion in the Iron Age.

\subsection{Celestial Bodies}

\subsubsection{Moon}

The moon and its various phases played an important role in the profane aspects of ancient Near East life in the marking of time. The moon also enjoyed a lively sacred history as a part of ritual calendars and in association with a variety of lunar deities. Deification and worship of the moon is attested across the ancient Near East, most famously at the Mesopotamian sites of Ur and Harran (by the names Nanna and Suen [=Sîn] respectively), where traditions of moon-god worship span several millennia (Green 1992; Margueron 1992). In the West Semitic sphere, second and first millennium epigraphic texts, mid-first millennium biblical texts, and a variety of iconographic material underscore the importance of the moon and the moon-god, whose name is usually derived from the West Semitic word for the moon, yrh (Schmidt 1999; Theuer 2000). In Ammon, there are a handful of items that make it clear that the West Semitic moon-god played an important role in Ammonite perception of nonphysical beings.

On the epigraphic side of things, two bits of evidence have come to light. A small statue, now generally called the Statue of Yarh' azar (CAI, no. 43), was found outside the Roman city wall on the north end of the Amman Citadel. The statue is carved from limestone and stands $45 \mathrm{~cm}$ high, and was found with traces of red paint on the body and garments (Barnett 1951, pp. 34-35, and pl. XI). Because the statue was not found in a secure archaeological context, it is usually dated to the late eighth or seventh century BCE, based on the script of the inscription on the pedestal base (CAI, p. 108). The partially preserved two-line inscription reads:

Line 1: [broken]šwyrh’ zr [broken]šw Yarh azar

Line 2: [broken] $k r$ br šnb ${ }^{14} \quad$ [broken]kr son of Šanib

Despite the broken parts of the inscription, it appears to preserve a chain of three generations with only the last two letters $(k r)$ of the middle generation being visible. Reconstructed, the names would most likely run as such: "Yarh' azar, [son of ?]kr, son of Šanib."

14 This has been read as either a " $\mathrm{b}$ " or " $\mathrm{p}$ " (CAI, p. 210). 
The grandfather mentioned at the end of the inscription is plausibly identified with "Šanipu of the House of Ammon," a king mentioned as paying tribute to the Neo-Assyrian monarch Tiglath-pileser III in 734 BCE (?, pp. 122-23, no. 47 [Summ. 7r. 10']B114-religions-432110) Whether this means that Šanipu's son and grandson were kings too, one cannot say for sure, but they were certainly related to one of the power-players in Ammon. Whatever Yarh' azar's specific status, his name includes the name of the West Semitic moon-god Yarah, and means "Moon is help." As a representation of what must have been a member of the Ammonite elite, the inscription shows that the West Semitic moon-god had a meaningful place in the Ammonite pantheon.

Apart from the statue of Yarh azar, only one other plausibly Ammonite inscription contains the yarah element. A badly burnt ostracon from Tall al-Mazar, Ostracon IV, has only one partially legible word that appears to read lyrh, "to Yarah." This could represent a sacrifice to the moon-god or something given to a person with the same name (CAI no. 145). The poor state of preservation of the ostracon precludes certainty.

Iconographic representations of the moon from the region of Ammon also attest to the worship of the moon-god. Two nearly identical architectural examples come from the site of Rujm al-Kursi, about $10 \mathrm{~km}$ west of the center of Amman, Jordan. There, on either side of the entrance to a building that is plausibly identified as a temple, are smoothed, nearly cubical blocks of limestone measuring slightly less than $1.0 \mathrm{~m}$ per side. On the front face of each block there is a relief presenting a lunar crescent standing on a table and supported by a pillar (Figure 3 ).${ }^{15}$ Inside the crescent there is a disk which may represent the full moon (Keel 1998, p. 113). The pillar on the better-preserved block shown in Figure 3 has two rectangles inside it. The pedestal or platform on which the pillar rests has feet rather than the solid or stepped pedestals known on other stelae and seals. Inside the table are two crossing lines that look like an ' $X$. ' The iconography of these reliefs is similar to the iconography of the crescent moon standard typical of the Mesopotamian moon-god Sîn of Harran. The main exception is that the standards here lack the tassels that are typical of the lunar crescent of Sîn of Harran (Hübner 2009 , p. 150), but stelae depicting the crescent standard without the tassels are known, even from areas closer to Harran (Keel 1998, pp. 63-64, figs. 3-4). As Keel points out, the thickened pillar, and the style of the platform have parallels on seals from the region (Keel 1998, p. 113, especially figs. 36-37). One wonders whether the ' $X$ ' inside the platform is a simplified version of the more extensive cross-hatching visible on some seals (Keel 1998, figs. 33-34, 38-39, 42-49). While a full analysis of this site must await the final publication of the excavations, the reliefs have been dated on stylistic grounds to roughly the seventh century $\mathrm{BCE}$, at the height of Assyrian power in the region. If the date is confirmed by the pottery, these reliefs will furnish evidence of the spread of the iconography of Sîn of Harran well into the Assyrian periphery. Whether this indicates the worship of Sîn of Harran in Ammon, or the adaptation of Sîn's iconography for application to the local moon-god Yarah is difficult to determine (Hübner 2009, pp. 149-50). Given the relative popularity of the moon-god among the Arameans in Syria, including stelae with moon-god iconography at Bethsaida and the Hauran to the northwest and north of Ammon (Bernett and Keel 1998; Keel 1998, pp. 116-20), moon-god traditions from Harran were most likely mediated through the Arameans. ${ }^{16}$

15 The Iron Age material from the site has not been published by the excavator, Abdel-Jalil 'Amr, who has since died. A brief note from 'Amr mentions Iron Age material in deep layers (Amr 1986). The material published from the site comes from the Roman, Byzantine, and Islamic periods. For bibliography see (Hübner 1992, p. 152, n. 121). The possible Iron Age temple and its reliefs were first discussed by Keel, who had been informed of the site by Ulrich Hübner (Keel 1998). Hübner later published an article on the site (Hübner 2009). Subsequent discussion of the possible temple can be found in (Elkowicz 2012, pp. 90, 114, Taf. 62, 66; Elkowicz 2014; Hübner 2015; Tyson 2014, pp. 37-39). The drawing from Keel (1998, fig. 105) was reproduced and mentioned briefly in Staubli (2003, p. 67).

16 Aramean cultural influence on Ammon can be seen in other ways, for example, the adoption of the Aramaic script in Ammon sometime in the late ninth or early eighth centuries BCE (Tyson 2014, pp. 102-4), and artistic influences visible in Ammonite sculpture from the eighth century BCE (Dornemann 1983, pp. 156-59; Zayadine 1991, pp. 49-51). 


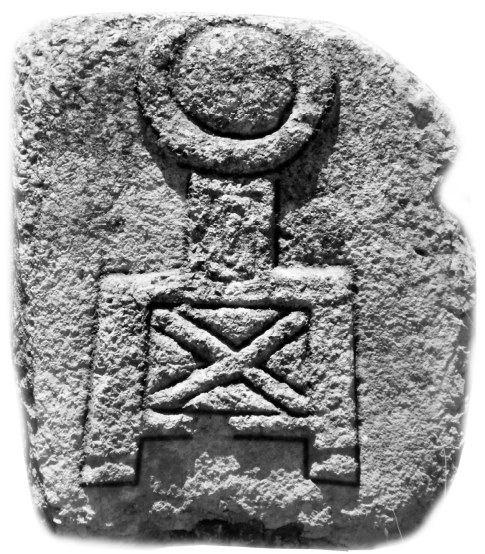

Figure 3. Lunar crescent relief from one side of the entrance to the Rujm al-Kursi building. Photo courtesy of the author.

The images on seals from Ammon likewise contribute to the evidence for the moon-god. Three main categories of seals are typical of the Iron Age II in Syro-Palestine and are based on shape: cylinder seals, conoid stamp seals, and scaraboid stamp seals. ${ }^{17}$ By all accounts, the scaraboid stamp seals represent the indigenous tradition of sealing. The cylinder seals that are somewhat common in Syro-Palestine during the Neo-Assyrian Period (734-612 BCE), and the conoid stamp seals that become more common in Syro-Palestine in the Neo-Babylonian and first part of the Persian Period (ca. 600-450 BCE), have their home in Mesopotamia (Keel and Uehlinger 1998, pp. 367, 374; Ornan 1993, pp. 52-53). ${ }^{18}$ As such, it is not always clear whether cylinder seals and conoid stamp seals found in Syro-Palestine represent local perceptions of the divine world. However, contemporary parallels in the iconography of the three main types suggest convergences of foreign and indigenous perceptions of the divine world.

Two cylinder seals from the region depict the standard of Sîn of Harran. On Nebo 1 (CSAJ, pp. 192-93) ${ }^{19}$ which dates to the 8 th-7th centuries BCE, two worshippers approach a tasseled crescent moon standard of Sîn of Harran (Figure 4a). The worshippers carry what are probably instruments, and are separated by ankh symbols. On the opposite side of the crescent moon standard is a stylized tree. The seal also has other astral symbols, including the eight-rayed star of Venus, and three dots, likely representing stars (CSAJ, p. 192; Keel and Uehlinger 1998, p. 302). Another cylinder seal dating to the eighth-seventh centuries BCE (CSAJ, pp. 306-7, Tall al-Mazar 23) shows two falcon-headed figures, which attend the tasseled standard of Sîn of Harran (Figure 4b). The scene also contains the eight-rayed star of Venus and a schematic, seven-dot representation of the Pleiades. On the outside of each of the figures are what seem to be stylized trees. ${ }^{20}$ An additional exemplar (CSAJ, pp. 356-57, Tall al-'Umeiri 78) with a less clear image appears to portray a crescent moon standard, along with other astral symbols (Figure 4c). While the iconography on these cylinder seals probably does not arise from local sources, it does illustrate the full repertoire of symbols and figures that could appear in such a scene. On stamp seals, which have less surface area, one tends to find more limited representations of worship scenes.

17 The term "scaraboid" as a description of the slightly oblong shape of these seals, comes from scarab seals, which have scarab beetles inscribed on the convex side of the seal.

18 The shape of a seal affects the amount of space for images and the way in which the seal is used. Cylinder seals are typically carved all the way around the cylinder, and when used for sealing, they create an image that repeats if rolled more than one rotation. Conoid and scaraboid stamp seals on the other hand, have a single main, roundish stamping surface that has a smaller space than what is typical on a cylinder seal, hence limiting what can be carved on it.

19 CSAJ = Eggler, Jürg, and Othmar Keel. 2006. Corpus der Siegel-Amulette aus Jordanien vom Neolithikum bis zur Perserzeit. Fribourg: Academic Press.

20 Two other cylinder seals that were purchased in Amman, and are hence not from a secure archaeological context, appear to have a crescent moon along with other astral symbols (CSAJ, pp. 58-59, 'Amman 87-88). 


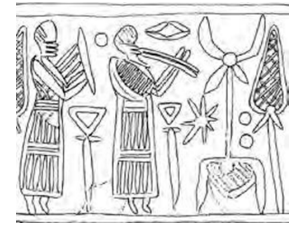

(a)

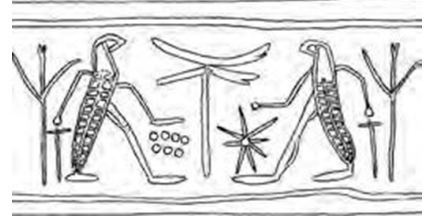

(b)

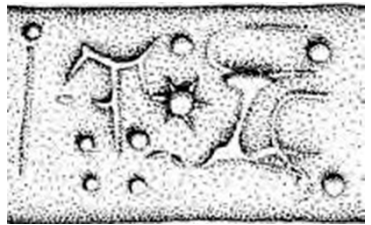

(c)

Figure 4. Cylinder seals with crescent moon standards: (a) Nebo 1; (b) Tall al-Mazar 23; (c) Tall al-'Umeiri 78.

A number of stamp seals from regions around Ammon depict the standard of Sin of Harran. The elements that flank the standard of Sin of Harran can be humans, plants, or some combination of the two (Keel and Uehlinger 1998, pp. 304-6). The total scene remains relatively stable, but the flanking figures alternate between a single person, two people, or a person and a stylized tree. One of the seals of this group seems to take the scene in yet another way. It appears to represent the deity in anthropomorphic form flanked by two stylized trees. This is arguably the moon-god, because the scene follows the pattern, and the figure is sitting on top of a low table or bench that is parallel to the bench on which the standard of Sîn of Harran usually sits (Keel and Uehlinger 1998, pp. 306-7).

In Ammon, two main variations appear on stamp seals. The first includes a worshipper with an upraised hand standing in front of several cult symbols, including a crescent moon. Four conoid stamp seals follow this pattern. In two of them with very similar styles from the 7th-6th centuries BCE ('Amman 3, Meqabelein 1; Figure 5a,b), there is a worshipper standing with their hand raised before a platform that houses the symbols of two Mesopotamian deities: the stylus of Nabu and the spade of Marduk. Above stands the crescent moon (CSAJ, pp. 10-11, 190-91). These scenes clearly emphasize the roles of Marduk and Nabu, but at the same time, they include the crescent moon. Two conoid stamps from Tall al-Mazar display worshippers before cultic symbols (Figure 5c,d). In the case of Tall al-Mazar 1 (sixth century BCE), the image shows a worshipper with their hand upraised before the lamp of Nusku, with a crescent moon at the top of the scene (CSAJ, pp. 296-97). A relatively minor god for much of Mesopotamian history, Nusku became more important in Neo-Assyrian times through an association with Sîn of Harran (Black and Green 1992, p. 145). Tall al-Mazar 14 (seventh century BCE) has two worshippers standing in front of the symbols of Nabu and Marduk. The top of the scene is filled out by astral symbols: the eight-rayed star of Venus, the crescent moon, and the winged sun disk (CSAJ, pp. 300-1).

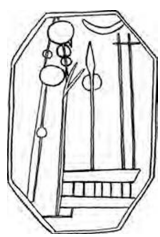

(a)

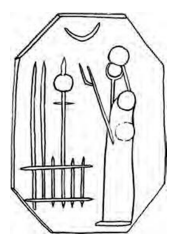

(b)

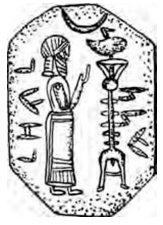

(c)

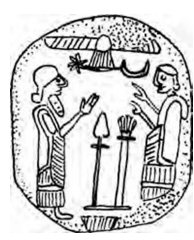

(d)

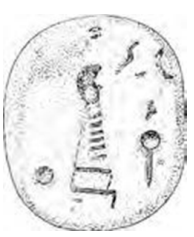

(e)

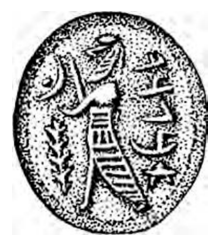

(f)

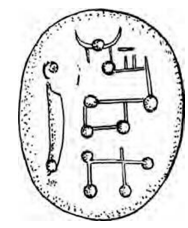

(g)

Figure 5. Stamp seals with worshipper and crescent moon: (a) 'Amman 3; (b) Meqabelein 1; (c) Tall al-Mazar 1; (d) Tall al-Mazar 14; (e) Tall al-'Umeiri 51; (f) Tall al-'Umeiri 52; (g) Umm Udeina 5.

Several scaraboid stamp seals also display a worshipper with a crescent moon. The best-preserved example is Tall al-'Umeiri 52 (8th-7th centuries BCE; Figure 5f). There is a worshipper-whether human or not is hard to tell-with both hands out towards a crescent moon with a full moon inside. In front of the figure is a branch or stylized tree (CSAJ, pp. 340-41). The limits of space on the seal mean much of the larger scene could not be included. The seal cutter retained the moon and the tree or branch that would otherwise flank the scene. Two others (Tall al-'Umeiri 51; Umm Udeina 5; 
Figure 5e,g) seem to preserve a similar scene with a worshipper before a crescent moon, but both are worn and somewhat difficult to decipher (CSAJ, pp. 340-41, 476-77). ${ }^{21}$

The second main variation includes an animal along with a crescent moon, which often also has a full moon inside it. Two conoid stamp seals fit this variation. 'Amman 4 (Figure 6a), which comes from the 6th-5th centuries, depicts a sphinx-like animal with what is perhaps a stylized ankh, as well as a crescent moon above (CSAJ, pp. 10-11). Tall al-'Umeiri 66 (Figure 6b), a seal from the seventh century, displays a quadruped with horns bending forward, a nursing child, and a very schematic set of celestial imagery above including what appears to be a lunar crescent (CSAJ, pp. 348-49). Several scaraboid stamp seals also fit this variation. Hisban 2, Tall al-Mazar 18, and Tall al-'Umeiri 11, and 54 all pair quadrupeds with a crescent moon (Figure 6c-f). On Tall al-Mazar 18 and Tall al-'Umeiri 11 the animals appear to be bovine, with bodies carved in three segments. Horns are clearly visible on the two bovines on Tall al-'Umeiri 11, while they are less clear on Tall al-Mazar 18. The exact animal on Hisban 2 and Tall al-'Umeiri 54 is a bit more difficult to discern, though both have horns curved backwards. All but Tall al-'Umeiri 54 contain a full moon inside the crescent moon (CSAJ, pp. 168-69, 302-3, 318-19, 340-41). Tall al-'Umeiri 4 (Figure 6g) is a seal impression on clay dated to the early sixth c. BCE, which combines lunar symbols with a scarab beetle (CSAJ, pp. 312-13; = CAI, no. 129). Flanking the beetle are two standards with a disc (perhaps a full moon) above which are downward facing lunar crescents.

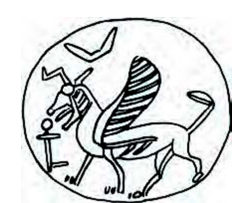

(a)

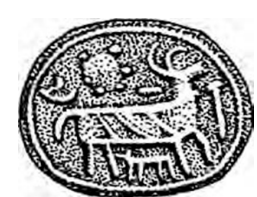

(b)

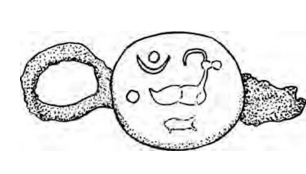

(c)

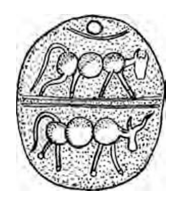

(d)

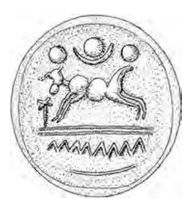

(e)

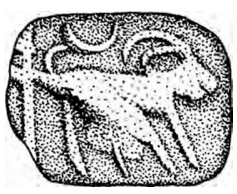

(f)

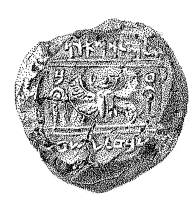

(g)

Figure 6. Seals with an animal and crescent moon: (a) 'Amman 4; (b) Tall al-'Umeiri 66; (c) Hisban 2; (d) Tall al-Mazar 18; (e) Tall al-'Umeiri 11; (f) Tall al-'Umeiri 54; (g) Tall al-'Umeiri 4.

A number of stamp seals have astral symbols without any other attending imagery. The badly damaged conoid stamp seal 'Amman 53 (seventh-sixth centuries BCE; Figure 7a) shows the crescent moon and the eight-rayed star of Venus (CSAJ, pp. 40-41). ${ }^{22}$ The scaraboid stamps seals Tall al-'Umeiri 39 (seventh-sixth centuries BCE; Figure 7b) and Umm Udeina 1 (eighth century BCE; Figure 7c) are both largely epigraphic, but 'Umeiri 39 has what appears to be a crescent moon with full moon at the bottom, and Umm Udeina 1 has a crescent moon and star (CSAJ, pp. 332-33, 474-75).

21 Cf. also the scaraboid seal Tall Deir 'Alla 28 from the nearby site of Tall Deir 'Alla (CSAJ, pp. 406-7).

22 Cf. Tall as-Sa'idiya 8 (CSAJ, pp. 370-71). 


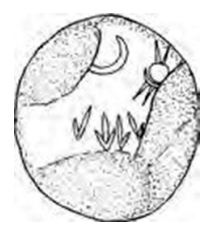

(a)

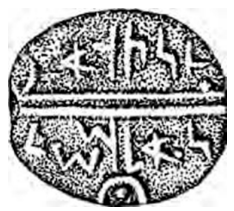

(b)

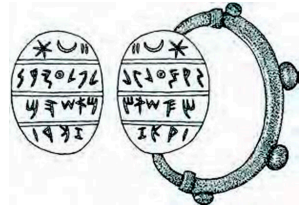

(c)

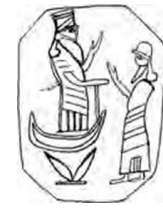

(d)

Figure 7. Seals with astral symbols: (a) 'Amman 53; (b) Tall al-'Umeiri 39; (c) Umm Udeina 1; (d) Amman 5.

A variation of Sîn iconography that is common in Assyria and the northern part of Syria between the ninth and fifth centuries BCE is an anthropomorphic deity standing in a crescent moon with a hand raised in a blessing posture (Keel and Uehlinger 1998, p. 309). A conoid stamp seal from Amman ('Amman 5) contains just such an image (Figure 7d). The seal, which probably dates to the seventh century BCE, has a deity standing in a crescent moon blessing a worshipper (CSAJ, pp. 12-13). ${ }^{23}$

The varied evidence available for the moon-god in Ammon-epigraphic and iconographicdemonstrates the active role that the moon-god played in Ammonite society. The cylinder seals that portray the standard of Sîn were most likely imported or came to Ammon with a trader or official from Assyria. The depiction of the lunar crescent on the six conoid stamp seals discussed above appears invariably alongside the symbols for other identifiably Mesopotamian gods (Marduk, Nabu, Nusku). Since the tradition of conoid stamp seals generally emanates from Syria and Assyria, it is possible to regard them as imports similar to the cylinder seals. The scaraboid stamp seals are, on the other hand, a distinctly Levantine tradition. The exemplars from Ammon preserve three main variants: a worshipper before a lunar emblem, a lunar emblem with an animal (bovine or other quadruped), and a lunar emblem with an inscription (in one case also including a star). Absent from the scaraboid stamp seals are Sîn's standard and the symbols of other Mesopotamian gods, and this fact makes the scaraboid stamp seals the most potentially polyvalent of the three types of seals found in Ammon. A crescent moon is a nearly universal emblem of moon-gods across the ancient Near East and thus could invoke any locally or more broadly known moon-god. Is there a way then to specify which moon-god is referenced in a specific context such as Ammon?

Given the occurrence of Yarah as a theophoric element in an elite Ammonite name, the default should be that these lunar emblems represent this local deity. However, the iconography of Sîn of Harran used on the reliefs at Rujm al-Kursi suggests a more complicated situation. Was Sîn worshipped in Ammon alongside Yarah? Was Sîn's iconography applied to the West Semitic moon-god Yarah? Or were Sîn and Yarah identified or otherwise thought to be the same deity? There is at present no way to answer the question definitively. Nonetheless, we do know that Sîn of Harran played a special role in Neo-Assyrian expansion and management of the western part of the empire. In part, this seems to be related to the location of Harran as a kind of gateway to Assyria's western periphery, but also because of the ease with which one moon-god could be identified with another (Holloway 1995, pp. 279-308). This reality favors the conclusion that some kind of identification took place between Sîn of Harran and the West Semitic Yarah.

Along different lines, iconographic analysis of the representation of deities in the first millennium BCE ancient Near East shows significant overlap and mixing of the iconographic attributes of the various local versions of the weather god and the moon-god. A particular point of similarity is their common attribute animal, the bull (Novák 2002; Ornan 2001, pp. 19-26). The mixing of such attributes is visible on seals, and reliefs on stelae and orthostats. Closest to Ammon is the stele from Bethsaida (Figure 8) that combines weather god, bull, and lunar symbolism in one figure (Bernett

23 An unprovenanced seal that may be from the region of Ammon seems to incorporate the boat motif, the stylized tree, and the anthropomorphic deity sitting on a bench facing an ankh (Keel and Uehlinger 1998, pp. 307, illus. 305a; Avigad and Sass 1997, p. 446, no. 1177). 
and Keel 1998; Ornan 2001). The apparent amalgamation or merging of weather god and moon-god iconographic features might well have taken place in Ammon given the connection between a lunar crescent and bovine figures on Tall al-Mazar 18 and Tall al-'Umeiri 11 (Figure 6c,d). Finally, as Keel and Uehlinger have shown, the night time celestial powers in general-the stars, Venus, and the moon-were popular in the iconography of Iron IIC seals from the Levant, similar to the way in which the sun and its iconography had been popular in the preceding Iron IIB (Keel and Uehlinger 1998, pp. 287-323). In this broad iconographic context, it is possible to see a further amalgamation of deity attributes in which state gods such as Yahweh and Milkom, who had already been identified with 'El, took on the additional imagery of the moon (Keel and Uehlinger 1998, pp. 306-16). Along these lines, Theuer has called attention to the seal of Milkom'or as highlighting the connection between Milkom and the moon. On the seal (Tall al-'Umeiri 4; CSAJ, pp. 312-13), the central register displays a four-winged scarab beetle flanked by two poles or standards with a ball (probably a full moon) inside a downward facing moon crescent. In addition to the clear lunar aspects of the iconography, Theuer notes that the second part of Milkom'or's name, which means "light," is a known epithet of the moon-god (Theuer 2000, p. 414). While we cannot reach a definitive conclusion on the amalgamation or identification of 'El, the weather god (which was usually the state god), and the moon-god in Ammon, the evidence is suggestive that some such process did take place. In addition, the imperial context of the evidence, with all of its pressures and opportunities for cultural exchange, was ripe for such processes. ${ }^{24}$

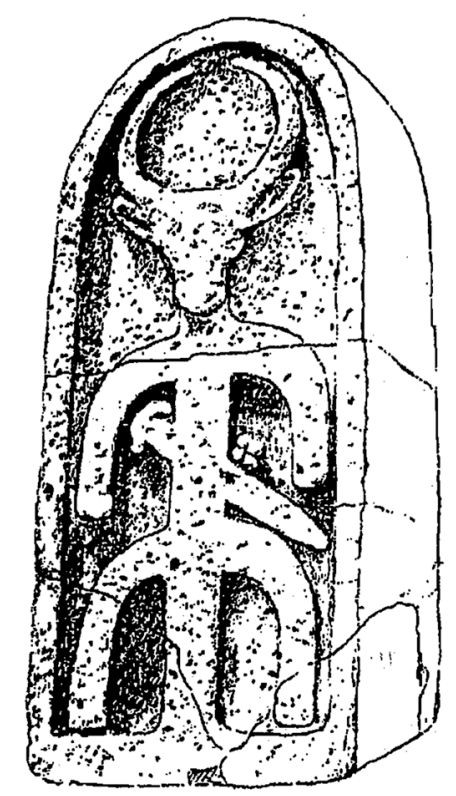

Figure 8. Stele from the gate area of Bethsaida from (Keel 1998, fig. 107). Note the bull head and horns that form a crescent moon.

\subsubsection{Sun}

Much less can be said about the status of the other celestial bodies in Ammon. With regard to the sun, its cyclical course across the sky, and its attendant ability to see everything, led to the association of the Semitic sun god (Šamaš) with justice (Black and Green 1992, p. 184). In Judah and Israel, solar imagery of largely Egyptian origin is common in the ninth and eighth centuries BCE, and

24 There is now a significant body of scholarship discussing the ways in which the conception of Yahweh of Israel and Judah slowly absorbed the attributes of other gods and goddess, eventually yielding something like monotheism. The key period for this is under imperial power, during the Neo-Assyrian, Neo-Babylonian, and Persian empires (ca. 730-323 BCE). On this topic, see (Dietrich and Klopfenstein 1994; Edelman 1996; Gnuse 1997; Smith 2001, 2002). 
associated with Yahweh rather than an independent sun god (Keel and Uehlinger 1998, pp. 256-61, 278-79; Lipiński 1999). The sun, along with the stars and the moon, was understood to be created and controlled by Yahweh.

In Ammon a few provenanced seals provide examples of solar imagery in the form of the sun disk. Four scaraboid stamp seals have the sun disk combined with an animal ('Amman 7; Tall al-Mazar 7, 8, 11; CSAJ, pp. 14-15, 298-301; Figure 9a-d). They are all dated to the 7th-6th centuries BCE. One conoid stamp seal from Tall al-Mazar depicts two worshippers facing the spade of Marduk and stylus of Nabu, and includes a winged sun disk, star, and crescent moon above the worshippers. It is dated to the seventh century BCE (Tall al-Mazar 14; CSAJ, pp. 300-1; Figure 9e). Tall al-Mazar 24, a cylinder seal from the eighth century $\mathrm{BCE}$, depicts two winged griffins, each facing a stylized palmette. A winged sun disk and ankh serve as a scene divider behind the two griffins (CSAJ, pp. 306-7; Figure 9f). ${ }^{25}$ In addition to the iconographic representations of the sun disk, one Ammonite ostracon from Tall Hisban that dates to the second half of the sixth century BCE includes the name šmšl (CAI, no. 137), which can be translated as "Šamaš (sun) is god," or "Šamaš is 'El."

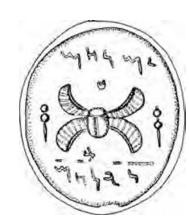

(a)

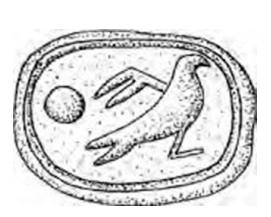

(b)

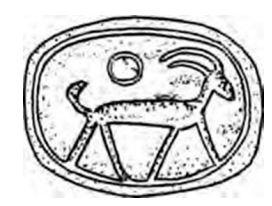

(c)

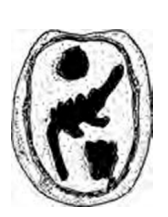

(d)

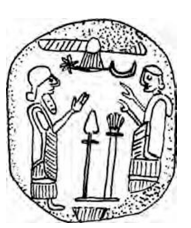

(e)

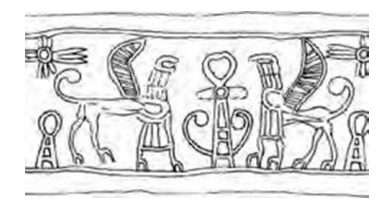

(f)

Figure 9. Seals with solar symbolism: (a) 'Amman 7; (b) Tall al-Mazar 7; (c) Tall al-Mazar 8; (d) Tall al-Mazar 11; (e) Tall al-Mazar 14; (f) Tall al-Mazar 24.

\subsubsection{Stars}

Alongside the moon and the sun, the stars were also objects of worship and fascination in the ancient Near East. Biblical texts variously view the stars as lesser gods, angels, or merely natural phenomena controlled by the god of Israel (Lelli 1999). Stars are visible on seals from across the southern Levant, often in association with the moon crescent, the eight-rayed star of the goddess Ištar (i.e., Venus), or both (Keel and Uehlinger 1998, pp. 292-94). The Pleiades, represented as seven dots (Black and Green 1992, p. 162) are also a common astral symbol on seals.

A number of seals from Ammon depict stars, often in association with the moon crescent and other symbols. The 8th-7th century BCE cylinder seal Tall al-Mazar 23 (Figure 4b) depicts the seven-dot Pleiades along with two falcon-headed beings, a moon crescent standard, and the eight-rayed star of Ištar (CSAJ, pp. 306-7). Nebo 1 (Figure 4a); another cylinder seal from the 8th-7th centuries BCE, depicts two worshippers standing before the crescent standard of Sîn. The eight-rayed star of Ištar also appears in this scene, along with several dot stars and ankh symbols (CSAJ, pp. 192-93). Two other cylinder seals portray stars. Dating to the 9 th-8th centuries BCE, 'Amman 88 depicts a worshipper standing before a seated god. In between them stands an altar, and in the upper part of the scene is a crescent moon and six triangles most likely representing stars (Figure 10a) (CSAJ, pp. 58-59). Tall al-Mazar 25 (Figure 10b), a cylinder seal that dates to the 8th-7th centuries BCE, depicts an animal in front of a standard holding a six-rayed star (CSAJ, pp. 306-7). Tall al-'Umeiri 78 (Figure 4c) has

25 Two non-provenanced seals display winged sun disks. A scaraboid stamp seal that is supposedly from Amman and probably dates between the end of the eighth and beginning of the 6th century BCE, depicts a winged sun disk in the middle of three registers with the owner's name split across the top and bottom registers ( $\varnothing^{\prime}$ Amman 74; CSAJ, pp. 50-51). There is also a scarab stamp seal supposedly from Salt, which dates to the Persian Period (end of 6th-5th centuries BCE), and hence may fall outside the temporal parameters of this paper. This piece depicts the Egyptian deities Isis and Harpokrates facing one another inside what appears to be a shrine. The roof of the shrine is depicted as a winged sun disk. Another sun disk without wings and yet another winged sun disk sit above the shrine roof (ØSalt 4; CSAJ, pp. 276-77). 
a six-rayed star, a moon crescent standard, and several dots presumably representing stars (CSAJ, pp. 356-57).

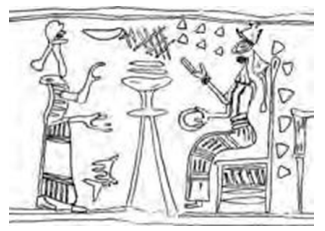

(a)

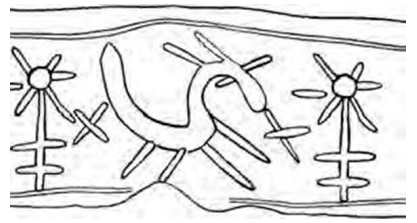

(b)

Figure 10. Seals with astral symbolism: (a) 'Amman 88; (b) Tall al-Mazar 25.

Three conoid stamp seals dating to the 7th-6th centuries BCE depict stars. The simplest of these is 'Amman 53, which depicts a crescent moon, a star, and plants (Figure 7a). The main scene in Tall al-'Umeiri 66 is of a cow with a calf beneath it, and above it a moon crescent and disk surrounded by dots most likely representing stars (CSAJ, pp. 348-49; Figure 6b). Tall al-Mazar 14 is by far the most complex of these scenes, depicting two worshippers before the symbols of Marduk and Nabu, with a winged sun disk, crescent, and star above (CSAJ, pp. $300-1$; Figure $5 \mathrm{~d}) .{ }^{26}$ Only one provenanced scaraboid stamp seal from Ammon depicts a star. Umm Udeina 1, which dates to the eighth century BCE (Figure 7c) is mostly taken up by an inscription identifying the owner. In the upper register there is a crescent moon and a six-rayed star (CSAJ, pp. 474-75). ${ }^{27}$

The sample of seals from Ammon containing stars is rather small, and hence it is difficult to draw too many firm conclusions from it. Given that the eight-rayed star of Ištar appears only on two of the cylinder seals, it is difficult to assess whether this goddess or her representative symbol had much impact in Ammon. The eight-rayed star of Ištar is known on scaraboid stamp seals from elsewhere in the Levant (Keel and Uehlinger 1998, pp. 292-97, illus. 288a, b, 289), and there is a linguistic-if not conceptual—connection between Ištar and the Levantine goddess Astarte (Pettinato 2005). The present state of the evidence, however, does not allow any firm conclusions for Ammon. ${ }^{28}$ The iconographic evidence for stars more generally, which is still not abundant for Ammon, does suggest a minor role in Ammonite religion especially in association with the moon.

\subsection{Other Gods, Goddesses, and Mythological Creatures}

A number of other deities and mythological creatures are attested to in the textual and material record from Ammon. From provenanced Ammonite inscriptions the following additional deity names are attested: 'Adon $(C A I$, no. 40$){ }^{29}$ 'Ali (CAI, no. 147:8), 'Anat (CAI, no. 211), Baga' (CAI, no. 147:3), ${ }^{30}$ Gad (CAI, no. 147:4), ${ }^{31}$ 'Ilon (CAI, no. 179), ${ }^{32}$ Nanay (CAI, no. 65:5, and possibly in 137:11), ${ }^{33}$ Qoš (CAI,

26 Non-provenanced conoid seals whose inscriptions might be Ammonite ØCAI, no. 1b (Ammonite or Aramaic).

27 ØSalt 5 is a very stylized non-provenanced scaraboid stamp seal dating to the seventh century BCE. In the upper part of the field between two worshippers is what appears to be a star (CSAJ, pp. 276-77). Other possibly Ammonite scaraboid stamp seals that depict stars are ØCAI, nos. 1, 8c (probably Moabite), 11, 17a (round, possibly Aramaic), 20 (probably Moabite), 28 , 29a (probably Aramaic), 31 (probably Moabite or Edomite), 69, 97 (probably Moabite), 98 (probably Moabite), 111, 126, 136, 142, 158, 190, 209.

28 On the possible connection between the "Queen of Heaven" mentioned in Jeremiah 7:18 and 44:17-25 and Ištar, see (Houtman 1999; Keel and Uehlinger 1998, pp. 292-94).

29 This deity name also occurs in the following non-provenanced inscriptions: ØCAI, nos. 17, 17a.

30 A Persian deity name.

31 Means "fortune," but also appears to be a deity name. This deity name also occurs in the following non-provenanced inscription that is probably Ammonite: ØCAI, nos. 127.

32 Linguistically related to 'El.

33 Consort of the Babylonian god Nabu. 
no. 238), ${ }^{34}$ and Yahu (CAI, no. 147:7).$^{35}$ While many of these deity names appear only once, the list demonstrates a diversity of gods and goddesses, ${ }^{36}$ including several that are normally associated with other regions (Baga', Nanay, Qoš, Yahu). ${ }^{37}$ The mechanisms by which non-native names made their way to the region are surely diverse, most likely including migration, commercial contacts, diplomatic, and military contact.

The iconography on seals found in Ammon attests to several other nonphysical beings that might have been known. It is possible that many of the conoid stamp seals listed below were produced elsewhere, but having been found in Ammon, some familiarity with the images on the seals is likely, even if that familiarity is not attached to a specifically named god, goddess, or other nonphysical being. As with the names from seals, some of which are of foreign origin, a number of the beings or symbols of gods originated from outside the region of Ammon and made their way to the area by a variety of mechanisms. From the available seals, the following nonphysical beings or their symbols are attested: 38

1. Bes-An Egyptian god known for his dwarf-like features and protecting pregnant women appears on the scarab seal 'Amman 62 found in a grave (CSAJ, pp. 44-45; Figure 11a). Figures of Bes have been found throughout much of the ancient Near East, (Black and Green 1992, pp. 41-42; Te Velde 1999). ${ }^{39}$

2. Gula-A Mesopotamian goddess of healing (Black and Green 1992, p. 101) appears on the conoid stamp seal 'Amman 5 (CSAJ, pp. 12-13; Figure 7d).

3. Lamp of Nusku-This symbol of a minor Mesopotamian god of fire and light who rose to some prominence during the Neo-Assyrian Period in connection with Sîn of Harran (Black and Green 1992, p. 145) appears on the conoid stamp seal Tall al-Mazar 1 (CSAJ, pp. 296-97; Figure 5c).

4. "Lord of the animals"-This polyvalent type scene, typically with a figure holding animals on either side was widely used in the ancient Near East and thought to represent many different deities (Eggler 2009). A cylinder seal from the tomb at Meqabelein that dates to the 6th-5th centuries BCE depicts an anthropomorphic figurine between two bulls (CSAJ, pp. 190-91, Meqabelein 2; Hübner 1993, p. 142). Given that it is a cylinder seal, it was probably imported and might originally have been meant to depict a Mesopotamian god. Locally, it might have represented Milkom.

5. Spade of Marduk-This symbol of the patron god of Babylon appears on a number of seals, all of which (with the exception of one bulla, i.e., a seal impression) are conoid stamp seals of the kind more common in Aramaean areas and Mesopotamia. They are the following: 'Amman 3 and

34 Name of the Edomite state god.

35 The name of the Judean and Israelite god. This deity name also occurs in the following non-provenanced inscriptions that have been identified by some scholars as possibly Ammonite: ØCAI, nos. 4, 9c.

36 A pair of statuettes that is most likely a male-female pair might represent 'El and his consort were found at Khirbat al-Hajjar (Ibrahim 1971; Abou Assaf 1980, pp. 21-22, tafeln I-II). One of the statuettes bears the atef crown and fits with the iconography of 'El discussed above. The other statuette appears to be female, though the face is damaged badly, and so an identification remains uncertain (Dornemann 1983, p. 157 n. 2). Four other female double-faced heads were found in secondary deposition on the Amman Citadel (Zayadine 1973, pp. 34-35, pls. XXI-XXIII). These were in all likelihood designed to be integrated into decorative architecture and viewed from both sides (Abou Assaf 1980, p. 83; Dornemann 1983, pp. 160-61; Prag 1987, pp. 123-25; Zayadine 1973, p. 34). A general identification of these as representing a goddess is possible though not by no means certain (Hübner 1992, pp. 265-66).

37 Non-provenanced inscriptions that are possibly Ammonite add a few more deity names to the list. Inscriptions that are non-provenanced but probably Ammonite include the following theophoric elements: 'Astarte (ØCAI, no. 56:4), Bes (ØCAI, no. 44 [there are major disagreements over how to decipher this inscription]), Dagon (ØCAI, no. 78a [the seal is damaged and difficult to reconstruct]), 'Ešem (ØСAI, no. 71b), 'Inurta (ØСAI, no. 55), and Mot (ØСAI, no. 44).

38 Several non-provenanced seals that are possibly Ammonite add several other deities or symbols to the list. ØCAI, no. 103 depicts a naked female with hands on her breasts. Hübner suggests she is a representation of the consort of Milkom, a dea nutrix figure (Hübner 1993, p. 142). A local adaptation of the Egyptian god Harpokrates is visible on ØCAI, nos. 110, 111 (Hübner 1993, p. 143).

39 Bes may also appear epigraphically in a name on the non-provenanced inscription ØCAI, no. 44. 
49 (CSAJ, pp. 10-11, 38-39), Meqabelein 1 (CSAJ, pp. 190-91; Figure 5b), Tall al-Mazar 14 (CSAJ, pp. 300-1; Figure 5d), Tall Safut 5 (CSAJ, pp. 436-37).

6. Stylus of Nabu-This symbol of the Babylonian god of writing (Black and Green 1992, pp. 133-34; Millard 1999, p. 607) appears on a number of seals from Ammon, often alongside the spade of Marduk. Together they were two of the most popular gods in Mesopotamia during the first millennium BCE (Millard 1999). All of the seals are conoid stamp seals except 'Amman 88, which is a cylinder seal, and Tall Safut 5, which is a bulla: 'Amman 3 and 88 (CSAJ, pp. 10-11, 58-59; Figures 5a and 10a), Meqabelein 1 (CSAJ, pp. 190-91; Figure 5b), Tall al-'Umeiri 44 (CSAJ, pp. 336-37); Tall Safut 5 (CSAJ, pp. 436-37).

7. Mischwesen-Mixed or hybrid beings are a common feature of ancient Near Eastern art and mythology. They compile features of multiple types of living beings (humans, birds, lions, bulls, fish) into a hybrid that then often serves as a protector of liminal spaces, such as temple entrances, as well as in other apotropaic functions.

a. Bull-man-Varying somewhat from depiction to depiction, a bull-man has the body of a bull, a human head, and sometime wings (Black and Green 1992, p. 51). One appears on the scaraboid stamp seal 'Amman 6 (CSAJ, pp. 14-15; Figure 11b), and on another scaraboid stamp seal, Tall al-'Umeiri 55 (CSAJ, pp. 342-43).

b. Genius-Genius is a generic name used to cover a number of figures with human heads and bodies with the addition of wings (Black and Green 1992, pp. 87-88). What appears to be a four-winged genius is visible on one side of the scaraboid stamp seal 'Amman 6 (CAI, no. 41; CSAJ, pp. 14-15), but the head area is damaged and hence impossible to know for sure. Another four-winged genius appears on Tall Safut 4 (CSAJ, pp. 436-37). ${ }^{40}$

c. Griffin-A mythological creature with leonine body and tail, wings, and an eagle/bird head (Black and Green 1992, pp. 99-101) appears on two conoid stamp seals 'Amman 4 and 54 (CSAJ, pp. 10-11, 42-43; Figure 6a). Two more appear on the cylinder seal Tall al-Mazar 24 (CSAJ, pp. 306-7; Figure 9f), with an additional example on the scaraboid stamp seal Tall Dschalul 2 (CSAJ, pp. 420-21). Two additional griffin-like figures appear on Tall al-Mazar 23, a cylinder seal, but the body type is difficult to identify (CSAJ, pp. 306-7; Figure 4b). ${ }^{41}$

d. Lion-demon (ugallu) - This creature has a lion head with upright ears or horns, a human body, and clawed bird feet (Black and Green 1992, pp. 119-21). It appears on the conoid stamp seal 'Amman 5 (CSAJ, pp. 12-13; Figure 7d). A second figure on the same side of this seal may be likewise be a lion-demon, but the area where the head would appear is damaged.

e. Mušuhuššu-This mythological protective beast is a mix of snake, lion, and bird, and over time was associated with several of the main gods of Mesopotamia, including Marduk, Nabu, and Aššur (Black and Green 1992, p. 166). It appears in stylized form on the conoid stamp seal 'Amman 49 (CSAJ, pp. 38-39; Figure 11d) in association with the spade of Marduk.

40 A non-provenanced scaraboid stamp seal that is possibly Ammonite has a four-winged humanoid wearing the Egyptian double crown and could possibly be considered a genius (ØСAI, no. 107). Another similar image appears on a scaraboid stamp seal that might be Ammonite, but is likely either Phoenician or Aramaic (ØСAI, no. 1a).

41 The following non-provenanced seals that are probably Ammonite have griffins as well. ØСAI, no. 17; ØCAI, no. 50 (scaraboid stamp seal); ØС $A I$, no. 55 (conoid stamp seal with griffin-like being). 


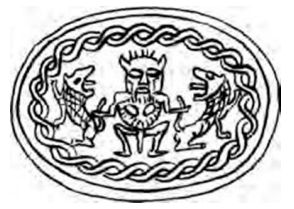

(a)

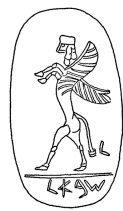

(b)

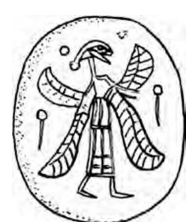

(c)

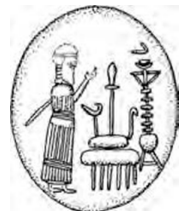

(d)

Figure 11. Other gods and mythological creatures: (a) 'Amman 62; (b) 'Amman 6; (c) Tall Safut 4; (d) Amman 49.

Noticeable in the iconography of these nonphysical beings is a significant bent towards beings whose origins are in Mesopotamia. This is not necessarily surprising, given the military and economic ascendency of Assyria and Babylonia in the late eighth through sixth centuries, which brought many other types of cultural borrowings to the Levant. Given that there are no mythological texts from the Ammonites, nor architectural representations of these beings from Ammon, we can say little about how they were perceived, whether they had names specific to the Ammonites, or how they fit within the Ammonite pantheon. Mentions in the Hebrew Bible of the Mesopotamian god Nabu (Isaiah 46:1) and the Egyptian god Bes (in a personal name; Ezra 2:49), along with descriptions of cherubim (e.g., Exodus 25:17-22; 1 Kings 6:23-38) and seraphim (Isaiah 6), that are Hebrew categories of Mischwesen, suggest that people in the southern Levant were aware of some foreign gods, and had indigenous categories of beings that paralleled those found in other areas. Without arguing that all of the gods, goddesses, and other nonphysical beings listed here were explicitly known in Ammon, the list provides a sense of the variety of beings that were understood to inhabit the nonphysical world of the Ammonites. That world was multilayered and populated by beings with varying roles to play in individual, family, and political life.

\subsection{Ancestors}

The status, role, and treatment of the dead in the ancient Levant, and more broadly the ancient Near East, has stimulated several decades worth of serious scholarly study that goes well beyond the scope of this essay. ${ }^{42}$ At a minimum, concepts of kinship linked the living and the dead, as did mortuary practices. Two main sets of evidence suggest the ongoing place of the dead within Ammonite society: (1) onomastic data, including the ethnonym or tribal name bn ' $m n$, "the sons of Ammon," and Ammonite personal names; (2) grave goods that indicate ongoing interactions with the dead.

\subsubsection{Onomastic Data Relating to the Ancestors}

The linguistic construction that refers to an individual as the "son of $X^{\prime \prime}$ or to a group as the "sons of $X$ " is common in the Semitic languages. In the case of an individual, the second part of the construction represented by the " $X$ " is normally that person's father. In the case of a group, the second part of the construction is normally the name of a real or fictive ancestor to which the group traces its roots (Routledge 2004, p. 126). The ways in which the Ammonites are named, both from within and without ${ }^{43}$, follows this model and suggests that "Ammon" is to be taken as the name of the eponymous ancestor of the Ammonites (Hübner 1992, p. 244). In addition to "Ammon" being in the

42 For recent discussion and bibliography see (Albertz and Schmitt 2012, chp. 5 and 7; Hays 2015; Herrmann and Schloen 2014; Porter and Boutin 2014; Stavrakopoulou 2010, pp. 1-28). Several earlier treatments of the dead and relations with them present different assessments of what the material and textual evidence can tell us are (Bloch-Smith 1992; Schmidt 1996; Van der Toorn 1996b, pp. 42-65, 151-77, 206-35).

43 The Tall Siran Bottle Inscription (CAI, no. 78) mentions three successive kings of the Ammonites all designated as mlk bn 'mn, "king of the sons of Ammon." In the cognate Hebrew language, the Hebrew Bible characteristically refers to the Ammonites as bny 'mn, "the sons of Ammon," (e.g., Genesis 19:38, Joshua 12:2), and less often as "Ammon" (e.g., 1 Samuel 11:11). In its records of the interactions with its imperial subjects, the Neo-Assyrian Empire refers to the Ammonites as "the house of Ammon," "the sons of Ammon," or simply "Ammon" (Tyson 2014, pp. 70-79). 
place of the eponymous ancestor in the ethnonym "the sons of Ammon," the name itself has ancestral overtones. This is because the name is built on the Semitic root ' $m(m)$ that has to do with clan or tribal relationships, particularly those on the paternal side. Depending on its use, it can refer to a paternal uncle, a paternal clan, more generically a kinsman, and in the plural, to groups of people (HALOT, pp. 837-38). ${ }^{44}$ It may be coincidence that the eponymous ancestor of the Ammonites has a name with ancestral overtones, for ' $m(m)$ is a productive noun in the West Semitic onomasticon (Jackson 1983, p. 515; Landes 1956, pp. 3-12). Nonetheless, one cannot help but wonder whether the eponymous ancestor was named with ancestral language for a particular purpose that is no longer discernable.

In addition to the use of ' $m(m)$ in the tribal name of the sons of Ammon, it also appears in the names of two Ammonite kings named 'mndb, "Amminadab," who are mentioned on the Tall Siran Bottle (CAI, no. 78) in a list of three kings, where the grandfather and grandson have the same name. A seal also bears the name Amminadab and most likely corresponds to the grandfather listed on the Tall Siran Bottle (CAI, no. 40). ${ }^{45}$ The name Amminadab, which appears in other Semitic languages as well, can be translated as "My kinsman is noble." 46

Several other Ammonite inscriptions contain kinship elements that add to the impression that deceased ancestors played a role in Ammonite understanding of the non-physical world. These include the following:

1. ' $b$, "father"-This element appears in the name 'bwt' $b$, "My father has longed for" (CAI, no. 243:2; Gane 2008, p. 77) It is conceivable that this name refers to a living father. For parallels and discussion of the use of ' $b$ see (Huffmon 1999b). ${ }^{47}$

2. ' $h$, "brother"-This element appears in the name ' $h$ ', which is the word for "brother", plus a hypocoristic ending that replaces the predicate (CAI, nos. 211:4; 243:1; Gane 2008, p. 76). For parallels and discussion of the use of ' $h$ see (Huffmon 1999a).

3. $h l$, "uncle"-This element appears in the name $h l$ ', which is the word "maternal uncle" plus a hypocoristic ending that replaces the predicate (CAI, no. 243:3; Gane 2008, p. 78; cf. ØCAI, no. 130).

44 It is possible that ' $m(m)$ could be the name of a god 'Amm. A lunar deity named 'Amm is known from South Arabian inscriptions from Qataban (in modern Yemen), but it is not clear that 'Amm was a deity known in the West Semitic sphere of which Ammon was a part (Hübner 1992, p. 243, n. 95; Seow 1999). It is also possible that it is an epithet of a deity-perhaps 'El or Milkom - who is thus referred to with kinship terminology. This use of ' $m(m)$ is possible for a name such as 'elli' $\bar{a} m$, "Eliam," which appears in the Hebrew Bible (2 Samuel 11:3) and can be translated as "My god is a kinsman" (Jackson 1983, p. 510), rather than "My god is 'Amm." A similar name occurs on a non-provenanced seal thought to be Ammonite (ØCAI, no. 10). However, gods are not normally referred to with kinship epithets other than 'b, "father" (Van der Toorn 1996a). Another issue with the name Ammon is understanding the morphology of the word (Hübner 1992, p. 243, n. 95). The difficulty stems from the $-n$ ending, which can be understood as a diminutive ending, thus yielding something like, "little uncle" (HALOT, p. 843). The $-n$ ending can also function as an adjectival ending (GKC $\S 86 \mathrm{f})$, which would hypothetically mean something like "ancestral." It can also be understood as a hypocoristic ending that replaces the theophoric element so common in Semitic names (Hübner 1992, p. 243, n. 95; Landes 1956, pp. 9-12). On this latter understanding, the name would have either asserted that a particular deity was a kinsman, or it would have ascribed some attribute or action to a deceased kinsman. GKC = Kautzsch, Emil, ed. 1910. Gesenius' Hebrew Grammar, 2nd ed. Translated by Arthur E. Cowley. Oxford: Clarendon. HALOT = Koehler, Ludwig, Walter Baumgartner, and Johann Jakob Stamm. 2001. The Hebrew and Aramaic Lexicon of the Old Testament. Study ed. Translated and edited under the supervision of M. E. J. Richardason. Leiden: Brill.

45 This name also appears in a seventh century BCE Assyrian inscription from the reign of Ashurbanipal, probably referring to the earliest of the three kings mentioned on this inscription. In the Assyrian inscription, which uses a syllabic script, the name appears as ${ }^{\mathrm{m}}$ am-mi-na-ad-bi LUGAL kur bit am-ma-na, "Amminadab, king (of the land) of the house of Ammon" (Borger 1996, pp. 19, 212). A non-provenanced seal thought to be Ammonite also contains the name Amminadab (ØCAI, no. 17).

46 For cognate names see (Jackson 1983, p. 515).

47 Several non-provenanced inscriptions that are possibly Ammonite include the noun for father in names. These include 'byb' l, "My father is Ba' al" (ØCAI, no. 1); 'b' l, "My father rises" (ØCAI, no. 22a); 'byhy, "My father is alive," or "The father has preserved" (ØCAI, no. 23); šm 'b, "The (divine) name is father" (ØCAI, no. 35); ' $b$ ', "Father" or "Father is ('El)" (ØCAI, no. 37a); 'bndb, "My father is noble" (ØCAI, no. 56); ' $h$ ' $b$, "The brother/kinsman is father" (ØCAI, nos. 98, 188, 216); 'btll, "My father is dew" (ØСAI, no. 143a); ' b' $d n$ "My father has granted fertility" (ØСAI, no. 152); 'b, "Father" (ØСAI, no. 180); ' $h t^{\prime} b$, "Sister of (my) father" (ØCAI, nos. 182); 'bh, "Father" (ØCAI, no. 205). 
4. $\quad h m$, "father-in-law"-This element appears in the name hmšgb, which can be translated as "My father-in-law is exalted" (CAI, no. 137:7; Jackson 1983, p. 512; Cross 2003, p. 83, with literature). ${ }^{48}$

It is not surprising that Ammonite names accord kin relations a place of honor, as is the case for the societies throughout the ancient Near East. Perhaps unique in this respect is the "sons of Ammon" tribal name, which traces tribal identity to an eponymous ancestor whose name itself has ancestral connotations.

\subsubsection{Grave Goods and the Ancestors}

A variety of tombs and one cemetery have been excavated in and around Amman, providing a glimpse into Ammonite funerary and mortuary practice in the Iron Age II. Tombs are normally cut into the rock or used natural caves. In the case of Tall al-Mazar Cemetery A, burials are in individual pits. The earlier burials, dating to the 11th eleventh through ninth c. BCE, tend to use coffins of some sort-whether anthropoid or large jars-and were buried with some pottery, jewelry, and an occasional seal. Burials from the eighth c. BCE through the Persian period do not use coffins. Grave goods from these tombs include a wide variety of ceramic vessels (jugs, bowls, flasks, decanters, tripod cups, chalices, lamps, juglets, painted bottles, and a few Assyrian style vessels), jewelry, and other metal items (kohl sticks, fibulae, bracelets, anklets, rings, earrings, mirrors, seals, arrowheads, knife blades, daggers, swords), figurines (female tambourine type, horse and rider, and one "hermaphrodite" in Amman Tomb C), a model shrine (Amman Tomb E), a bronze censer (at Umm Udayna), and other high status or unusual items (Mediterranean shells, Assyrian style pottery, seals, and items made of glass most likely imported from the Aegean. ${ }^{49}$

From this brief review, it is clear that the tombs in the vicinity of Amman represent what must have been the wealthier class. The much poorer individual burials at Tall al-Mazar Cemetery A highlight the wealth of the tombs found closer to Amman (Yassine 1984, 1999). Second, and more important for a study of beliefs about and practices related to the dead, is that the assemblage of ceramic vessels (especially tripod cups, chalices, juglets, and lamps), figurines, as well as the high status or unusual finds, is similar to that which Daviau isolates as relating to the domestic cult (Daviau 2001; on which see below $\S 4$.2.1). The question then is, what can we say about the religious aspects of these burials?

Some of the items found in the tombs, such as kohl sticks, jewelry, and seals, are personal items that represented the identity of the person interred rather than any specific religious practice. On the other hand, the number of pottery vessels generally associated with eating and drinking (but not storage) point to a nourishment of the deceased in their ongoing existence-whatever it was conceived to be. Lamps suggest the presence of the living in the tombs on some occasion. Some items were possibly used for fumigation (incense burners, and possibly tripod cups). Seals found in tombs are often thought of in functional categories, but they might also have served apotropaic purposes. Figurines and model shrines ${ }^{50}$ were probably used in some type of ritual practice that was related to the dead, but they are also found in non-mortuary contexts, suggesting that there was a range of uses for these objects. The form that such rituals took and the beliefs that they might imply are difficult to pinpoint. Nonetheless, it is reasonable to assume that such rituals were understood to have salutary effects upon the dead, as well as on relationships between the dead and the living.

At a minimum, it seems that the dead were understood to have a continued existence and need of sustenance that the living could provide. Commemorative acts were also common (Albertz and

48 Cf. ØСAI, no. 9, which contains the feminine name ' $l \breve{s} g b$, "'El is exalted." Here, the theophoric element is clearly a deity, and uses the same predicate. For more on this name and inscription, see (Hübner 1992, p. 69; Jackson 1983, p. 511). ØCAI, no. 215:1 uses the $h m$ element in the name $h m d n$, "My father-in-law is judge."

49 For a summary of the tombs, see (Tyson 2014, pp. 23-26, 30, 39-45, with literature).

50 For recent discussion of figurines and some of their possible uses, see (Darby 2014). For the collection and analysis of the Iron Age model shrines, see (Daviau 2008). 
Schmitt 2012, pp. 455-69; Bloch-Smith 1992, pp. 122-26; Schmidt 1996, p. 275). A cult of the dead or cult of the royal ancestors has been assumed for Ammon, in part based on discussions of other areas in the Levant (Hübner 1992, p. 279; Israel 1990, pp. 323-24). Certainly, the pottery related to food, figurines, and items related to incense are suggestive of rituals involving eating. Whether the tomb assemblages imply worship, placation, or other forms of manipulation of the dead is more difficult to know. If we take the definition of religion presented at the beginning of this paper as the starting point, then a distinction between the feeding and care of, or the deification and worship of ancestors becomes less important for the bigger picture. The extant material remains in tombs suggest that the dead in Ammon fall in the category of nonphysical agents (rather than being non-existent), and that there were beliefs and ritual practices associated with them, even if we cannot fully reconstruct them.

\section{Cultic Space}

For the purposes of this paper, I divide spaces used for relating to the nonphysical world into two broad categories: public cultic space and private or domestic cultic space. By the term "public cultic space" I mean only that the space seems to be intended to be used by a group that is most likely larger than a single family. A public cultic space is thus not contained within a domestic space even if it is physically built next to domestic buildings. By "private or domestic cultic space", I designate those spaces which appear to have some cultic or religious significance, but which are contained within a house, or in the case of tombs, relate to individuals or individual families. These are pragmatic distinctions used in part because of the dearth of remains and their state of preservation that does not allow for more refined analyses.

\subsection{Public Cultic Space}

The history and archaeology of the Iron Age II Levant furnish examples of a range of public cultic space types. The most well-known of these come from the Hebrew Bible, whose texts describe a portable public shrine known as the tabernacle (Exodus 25-31, 35-40) and then the more permanent temple said to have been built by Solomon (1 Kings 6) and then later destroyed in 586 BCE when the Babylonians destroyed Jerusalem and its temple (2 Kings 25:8-10). It is also clear from the Hebrew Bible that other public cultic spaces existed, though they are polemicized as illegitimate. In one of the classic passages describing the destruction and desecration of illegitimate places of worship we hear of the radical actions ordered by the reformer king, Josiah and of some of the places at which people were engaging in religious actions. The types of places mentioned are set in boldface to make them more visible.

The king commanded the high priest Hilkiah, the priests of the second order, and the guardians of the threshold, to bring out of the temple of the LORD all the vessels made for Baal, for Asherah, and for all the host of heaven; he burned them outside Jerusalem in the fields of the Kidron, and carried their ashes to Bethel. He deposed the idolatrous priests whom the kings of Judah had ordained to make offerings in the high places (bāmôt) at the cities of Judah and around Jerusalem; those also who made offerings to Baal, to the sun, the moon, the constellations, and all the host of the heavens. He brought out the image of Asherah from the house of the LORD, outside Jerusalem, to the Wadi Kidron, burned it at the Wadi Kidron, beat it to dust and threw the dust of it upon the graves of the common people. He broke down the houses of the male temple prostitutes that were in the house of the LORD, where the women did weaving for Asherah. He brought all the priests out of the towns of Judah, and defiled the high places where the priests had made offerings, from Geba to Beer-sheba; he broke down the high places of the gates that were at the entrance of the gate of Joshua the governor of the city, which were on the left at the gate of the city. The priests of the high places, however, did not come up to the altar of the LORD in Jerusalem, but ate unleavened bread among their kindred. He defiled Topheth, which is in the valley of Ben-hinnom, so that no one would make a son or a daughter pass through fire as an offering to Molech. He removed the horses that the kings of Judah had dedicated to the sun, at the entrance to the house of the LORD, by the chamber of the eunuch Nathan-melech, which was 
in the precincts; then he burned the chariots of the sun with fire. The altars on the roof of the upper chamber of Ahaz, which the kings of Judah had made, and the altars that Manasseh had made in the two courts of the house of the LORD, he pulled down from there and broke in pieces, and threw the rubble into the Wadi Kidron. The king defiled the high places that were east of Jerusalem, to the south of the Mount of Destruction, which King Solomon of Israel had built for Astarte the abomination of the Sidonians, for Chemosh the abomination of Moab, and for Milkom the abomination of the Ammonites. He broke the pillars in pieces, cut down the sacred poles, and covered the sites with human bones.

Moreover, the altar at Bethel, the high place erected by Jeroboam son of Nebat, who caused Israel to sin-he pulled down that altar along with the high place. He burned the high place, crushing it to dust; he also burned the sacred pole. As Josiah turned, he saw the tombs there on the mount; and he sent and took the bones out of the tombs, and burned them on the altar, and defiled it ... (2 Kgs 23:4-16a).

The clear polemical tone and purpose of this text means that a lot of questions remain about the seeming ubiquity of the "high places"; nonetheless it gives some sense of the range of public cultic spaces that are visible to the biblical author. Among other things, we hear of the bammot, "high places," high places at the gates, the Topheth (apparently a place for child sacrifice), houses of haqq $q^{2}$ dēšm , "the holy ones" (often thought to be male prostitutes), and altars in other places (roofs, in the Temple, in Bethel). Some of these spaces are understood to have cultic functionaries (i.e., priests) and paraphernalia such as pillars/standing stones (mașṣebôt) and poles ('ăšêrîm; related to the name of the goddess Asherah).

Archaeological excavations provide examples of a range of public cultic spaces as well. Iron Age II temples of varying sizes and construction have been excavated at sites such as Tell Tayinat in southern Turkey (Haines 1971, pp. 53-55; Harrison and Osborne 2012), Tel Dan (Davis 2013) and Arad in Israel (Aharoni 1968; Herzog et al. 1984), and Deir 'Alla in Jordan (Franken 1969; Hoftijzer and van der Kooij 1991; Ibrahim and van der Kooij 1991). Small yet public cultic spaces have been discovered at gates such as at Bethsaida (Bernett and Keel 1998). Shrines separate from urban areas have been excavated at sites such as Kuntillet 'Ajrud (Meshel 2012), and at Tell Damiyah (Petit and Kafafi 2016) ${ }^{51}$ and Wadi ath-Thamad WT-13 in Jordan (Daviau and Steiner 2017). Given this cross-section of public cultic spaces known from the Levant, it is to be expected that the Ammonites had a similar range of sites even though the extant textual and archaeological records provide only a few hints and clues to their existence. ${ }^{52}$

\subsubsection{Rujm al-Kursi}

The site of Rujm al-Kursi discussed above in relation to the moon-god (§ 4.3.1), despite not being fully published, may well provide the clearest example of an Ammonite temple or sanctuary. The major remains excavated at the site have been Byzantine or Umayyad in date (Hübner 2009, p. 146). Although it has not been excavated yet, the contours of an Iron IIC building that might be a temple are visible (Figure 12).

51 Tell Damiyah is very close to the traditional border of the Ammonites along the Zarka River, and might eventually prove to be Ammonite as excavations progress further. Regardless of its political affiliation, which we may never know for sure, its location near a ford in Jordan River make it a potentially important node for traffic through the area.

52 For recent discussions of temples and other cult places in the Levant and the ancient Near East, see (Elkowicz 2012; Hundley 2013). 


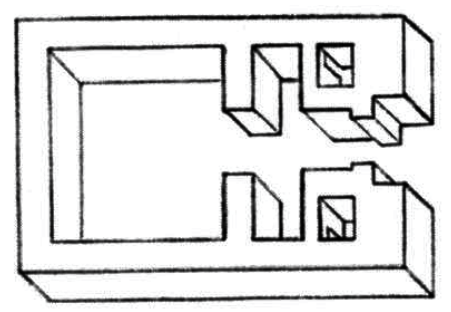

Figure 12. Isometric plan of the Rujm al-Kursi temple (Hübner 2015, p. 194, abb. 3).

The structure is oriented east-west, with the entrance facing east, an orientation typical of Iron Age temples. The outer dimensions of the structure are approximately $18.70 \mathrm{~m} \times 12.60 \mathrm{~m}$, with walls $1.50-1.60 \mathrm{~m}$ thick. The walls on either side of the entrance are $2.60 \mathrm{~m}$ thick. On either side of the entrance, there is a smoothed, nearly cubical block of limestone measuring slightly less than $1.0 \mathrm{~m}$ per side. On the front face of each block there is a relief presenting a lunar crescent standing on a table supported by a pillar (Hübner 2009, pp. 147-49; Figure 3).

The location of these reliefs at the entrance to the building suggests its identification as a temple to a moon-god. Compared with other representations of crescents in Syro-Palestine, the reliefs probably date to the seventh century; a more secure dating must wait for full publication of the pottery and excavations of the site. If the building does date to the seventh century, it furnishes evidence for the development of the region under Neo-Assyrian rule, and may provide evidence for the local adoption of the worship of Sîn of Harran, or at least the use of a symbol very much like his (Hübner 2009, pp. 149-51). ${ }^{53}$

\subsubsection{Amman Citadel}

The Amman Citadel, which stands near the center of the modern city of Amman, was the capital of the Ammonite kingdom. In the Bible, the site is called Rabbah of the Ammonites (i.e., "the great [city] of the Ammonites"). It was common in the ancient Near East, as it is in some places even today, for political and religious power to be connected in capital cities. Often palaces and temples were built near each other, and this might in fact be the case for the Amman Citadel. The partial remains of a large building dating to about $700 \mathrm{BCE}$ were located on the second plateau of the Amman Citadel. The extant remains of the building measure $10.0 \mathrm{~m}$ by at least $15.0 \mathrm{~m}$, and appear to be built in Assyrian open-court architectural style (Humbert and Zayadine 1992, pp. 249-58; Zayadine et al. 1989 , p. 362). Close to this building, four bifacial female stone heads were found built into a Hellenistic drain. Each head has two faces back-to-back such that they look essentially identical from either side. Each head has holes drilled in the top and the bottom suggesting that they may have been a decorative architectural function as part of a balustrade or other architectural feature (Abou Assaf 1980, p. 83; Dornemann 1983, pp. 160-61; Prag 1987, pp. 123-25; Zayadine 1973, p. 34). Whether or not the bifacial female heads were actually in the large building found nearby remains a matter of speculation; nonetheless, the building and the decorative architectural elements point to elite buildings of some sort (a palace?), and confirm the nature of the occupation on the Amman Citadel during the latter part of the Iron Age II.

53 Many questions remain about this building and its architectural context that cannot be answered until the excavations have been properly published, and even then, further excavations might be necessary to clarify the layout of the building and its relationship to other buildings in the same stratum. One aspect of the architecture that is debated is the building's relationship to other temple types known in the ancient Near East. Hübner maintains that the architecture is a combination of Migdal temple architecture with Syrian Langraum ("long room") temple types (Hübner 2009, 2015). Elkowicz on the other hand, argues that the two structures on either side of the entrance, which Hübner identifies as towers, are not towers, and hence, the Migdal temple identification is incorrect (Elkowicz 2012, p. 90; Elkowicz 2014). While I remain hesitant to draw definite conclusions about the structure because of the lack of excavation reports and vagaries of the interior architecture, I visited the site in July of 2012 and agree with Hübner that the structures on either side of the entrance look very much like towers with a small entrance to each from the interior (west) side. 
Given the elite nature of at least part of the Amman Citadel, it is a reasonable assumption that there was a temple or temples located somewhere nearby as well. Excavations conducted on the first plateau of the Amman Citadel just outside and under the Roman temple of Hercules uncovered a building dating to the seventh-sixth century BCE. The exposed portion of the building consists of an east-west wall $21.30 \mathrm{~m}$ long and a north-south wall $6.0 \mathrm{~m}$ long. A wall found in another square may continue the north-south wall, bringing its length to about $19.0 \mathrm{~m}$. The walls are made of an irregular collection of large and small stones, and they have a preserved height of 1.2-1.9 m and width of $0.7-1.0 \mathrm{~m}$. The plaster floor stands on top of an earth and stone layer used to create a level surface above the bedrock. There is no evidence for partition walls in the exposed part of the building, which points to a rather large (public?) room. Finds include Iron IIC pottery, a partially legible ostracon, figurine fragments, a part of a model, ${ }^{54}$ beads, spindle whorls, and some shells (Momani et al. 1997, pp. 160-70). The size of the building and its location under the Roman temple of Hercules may suggest a temple (Momani et al. 1997, p. 164). The reuse of sacred precincts through time is relatively common, and that may be what we see here. Speaking against such an interpretation of the Iron Age remains is the relatively crude construction of the walls, and the rather mundane collection of pottery and domestic objects.

A few other finds are suggestive of cultic space at the Amman Citadel. The Amman Citadel Inscription (CAI, no. 59) might provide some evidence for cultic architecture. This inscription on stone was discovered in 1961 in the remains of Iron Age fortifications on the southwest crest of the Amman Citadel. It was seriously damaged in antiquity when it was cut for use in a building and hence, only eight lines or partially readable text are left. The first partially preserved line seems to mention the name of the Ammonite god Milkom and a command to build an entryway or some kind of defensive structure (CAI, no. 59). Assuming the reconstruction of the partially preserved name Milkom is correct, it is possible that Milkom is seen as commanding the building of some sacred architecture. The badly preserved text precludes certainty. ${ }^{55}$

The nine male stone sculptures mentioned above ( $§ 4.1)$, which most likely represent 'El, also suggest the presence of a sacred precinct on or near the Amman Citadel. One of them was found on the Amman Citadel (Abou Assaf 1980, pp. 22-23, statuette III; Barnett 1951, p. 34 sculpture A, pl. X), two of the heads were found near Amman (Abou Assaf 1980, pp. 24-25, head VII, pp. 30-31, head XVII), two were purchased in Amman (Abou Assaf 1980, pp. 23-24, head V, p. 32, head XX), and three are of unknown provenance though likely from around Amman (Abou Assaf 1980, p. 23, head IV, p. 24, head VI, pp. 31-32, head XIX). Of these nine sculptures, the one found on the Amman Citadel is a full statue on a pedestal (Figure 2), the other eight are only the heads. The find of a stone torso on the Amman Citadel with a socket into which a head could fit (Abou Assaf 1980, p. 27, statuette fragment X; Barnett 1951, p. 36, sculpture D, pl. XIII), suggests that these the male heads might have been carved separately and attached then attached to the rest of the statue. There is no way to be certain that these sculptures were related to a temple, because all of them were found in secondary contexts or purchased on the antiquities market. Nonetheless, as statues representing a god or gods, an original cultic context is likely, even if we do not know its whereabouts precisely. ${ }^{56}$ Given their concentration in and around Amman and the Amman Citadel, the case for a temple there is strengthened. ${ }^{57}$

54 Presumably a model shrine, but the excavation report does not specify (Momani et al. 1997, p. 167).

55 The Amman Theatre Inscription (CAI, no. 58) also seems to contain a command to build something. This inscription is such a tiny piece of what it probably was originally that it is very difficult to tell.

56 It is possible that the story about David conquering Rabbah of the Ammonites (presumably the Amman Citadel) found in 2 Samuel 12:26-31 and 1 Chronicles 20:1-3 that describe David taking the crown off of Milkom or "their king" and putting it on his own head, might be reference to the despoliation of cult statue of Milkom. On this see the discussion above in $\S 3.1$.

57 For more bibliography see (Tyson 2014, Appendix B). 


\subsubsection{An Open Air Sanctuary at Tall al-'Umayri?}

A relatively large, apparently open-air structure with plastered floors was excavated in the Late Iron Age I Strata 11-10 (ca. 11th c. BCE) in Area H at Tall al-'Umayri. Several fragments of model shrines were found on the floor, and in the middle of the area, there is a stone, perhaps used for presentation or as an altar. Given the religious implications of the model shrine fragments, the excavators suggest the area is an open-air sanctuary (Herr and Clark 2009, p. 89). ${ }^{58}$ What is important here is that one of the floors from the following Strata 9-8 (ca. 10th-9th c. BCE) might continue this building into the Ammonite period under consideration here (Herr and Clark 2009, p. 90). While the evidence is not overwhelming for the continuance of this potentially cultic space into the Iron Age II, it is suggestive..$^{59}$

\subsubsection{Gate Cult at Tall al-'Umayri}

What is most likely a small cult corner was uncovered in Field $\mathrm{F}$ at the entrance to the late Iron IIC settlement at Tall al-'Umayri, consisting of a standing stone $0.90 \mathrm{~m}$ tall and a cobble-lined pit or basin (Herr and Najjar 2001, p. 337; Low 1991, p. 187). Cultic areas outside city gates have been found at Tirzah, Dan, and Bethsaida (Zevit 2001, pp. 149-53, 191-96, 238-41). The excavator compares this one specifically to the Stratum VII gate at Tell el-Far'ah (North), which also had a standing stone and a basin (Low 1991, p. 187). Though their function is not fully known, the basins and associated pottery suggest that people entering the city may have paid homage to the city god(s) by pouring or sprinkling water, or there may have been some significance to the association of the water and the stones (Zevit 2001, pp. 153, 192-94, 241). What we can say for sure is that these installations testify to public expressions of religiosity that may have focused on the local (perhaps city) $\operatorname{god}(\mathrm{s}){ }^{60}$

\subsection{Private or Domestic Cultic Space}

Identifying private or domestic cultic space can be challenging because it often lacks architecture that is easily identified as cultic. Cultic interpretations of a private or domestic nature are thus normally dependent on identifying an assemblage of artifacts that point beyond mundane daily life. Daviau describes such assemblages as "those artifacts and ceramic vessels which are present in uncontested shrine sites, but may also appear in a domestic setting as evidence of religious activities practiced by family members in the home" (Daviau 2001, p. 199). ${ }^{61}$

\section{Domestic Cult at Tall Jawa}

A domestic cult assemblage has been identified in several rooms at Tall Jawa. When excavated, the interiors of a number of buildings were found to have a thick layer of debris approximately $1.0 \mathrm{~m}$ thick in which a collection of items that parallel other known cultic assemblages in Israel and Judah

58 On the model shrine see (Elkins 2017).

59 For further bibliography see (Elkowicz 2012, p. 89).

60 Another example of public cult just to the south of Ammonite territory in Moab comes from a room just inside the city gate at Khirbat al-Mudayna ath-Thamad. The cultic nature of this room is easily identified by the existence of three small stone altars, benches along the walls, two female figurine heads, and the naked torso of a third, two bronze rings, a Wadjet-eye amulet, carved limestone "pegs," and a ceramic assemblage of lamps, a spouted vessel, a juglet, a decanter, small bowls, a small jug, and some store jars (Daviau and Steiner 2000). The three stone altars provide the most specific evidence in terms of actual practice. Two of them (the unpainted altar MT-4/014 and the conical altar MT-4/015) had soot on the top indicating that something was burned there, probably some king of incense or aromatic substance (Daviau and Steiner 2000, pp. 10-11). The tall conical one also has an inscription on it that reads "The incense altar [mqtr] that Elishama made for ysp, the daughter of ' $w t$ ' (Dion and Daviau 2000, p. 5), and thus confirms the function inferred from the burning. The painted altar (MT-4/011) has a small hole that connects to a larger depression that is likely used for drainage of liquid offerings (Daviau and Steiner 2000, p. 10). Taken together with the other finds, one can imagine this shrine as a place in which inhabitants of the city made small offerings or left a votive and prayed for divine assistance.

61 In this regard, Daviau builds on Holladay's essay on Israelite religion (Holladay 1987), which emphasized the importance of such an approach in identifying loci of domestic and other small-scale religious practices. 
were found. This layer separated the cultic material from the pottery that was smashed on the floor, suggesting that this material came from the roof or upper story (Daviau 2001, p. 202). ${ }^{62}$ Among the assemblage were "male and female figurines, zoomorphic figurines or vessels, one-handled cups, chalices, tripod cups, lamps, strainer bowls, small vessels, miniature vessels and basalt trays", as well as unique items such as a possible baetyl (a sacred stone), a Tridacna dish (a dish made from a giant clam), imported vessels, and a libation table (Daviau 2001).

That the material came from the upper level is significant because texts from Late Bronze Age Ugarit (coastal Syria) and Emar (northern Syria), as well as biblical texts dating from the seventh century BCE and later, mention cultic acts performed on roofs (Daviau 2001, p. 201). The prophet Ezekiel issues this judgement on the people of Jerusalem: "The Chaldeans [i.e., Babylonians] who are fighting against this city shall come, set it on fire, and burn it, with the houses on whose roofs offerings have been made to Baal and libations have been poured out to other gods, to provoke me to anger." Far from being a full explanation of domestic rituals on roofs, this and other texts nevertheless provide some clues for the uses of such an assemblage as that found at Tall Jawa. Specifically, it indicates that offerings (probably of the plant or incense variety) and libations (fluid offerings) took place on the roofs of city-dwelling individuals. For the assemblage at Tall Jawa, Daviau proposes the following set of possible activities that took place in these domestic spaces:

... the setting up of a figurine or symbolic stone in a particular area on the roof or upper storey, food and drink offerings, use of scented materials, lighting of lamps, sprinkling of the figurine, the baetyl, or the sacred area itself, offerings in small or miniature vessels, casting of lots or divination, and libations. (Daviau 2001, p. 221)

Whatever set of rituals this assemblage represents, it is likely that they were designed to invoke or create closeness with the gods or otherwise amplify the experience and effectiveness of communication with the gods (Keel and Uehlinger 1998, p. 348; Zevit 2001, p. 274). Given the regular finds of some of these items at other sites-especially figurines-it is probably a good assumption that small-scale cultic practices were common in Iron Age II Ammonite homes. ${ }^{63}$

\section{Religious Specialists}

The evidence for gods and goddesses as well as cultic space and associated practices implies the existence of religious specialists (priests, diviners, prophets, etc.) and rituals (offerings, divination, ecstatic utterances, etc.) about which we know little specific. ${ }^{64}$ One indication of a tradition of religious specialists close to Ammon comes from the famous site of Deir 'Alla where the plaster inscription of Balaam son of Beor, a seer $(h z h)$ known from the Bible (Numbers 22-24) was found. The function of room EE335 (the room containing the Balaam texts written on the wall plaster) at Tall Deir 'Alla is generally considered to be religious in nature because of the content of the text itself. The benches in the room also suggest a cultic function (in connection with the texts), because other known sanctuaries have benches in them, ${ }^{65}$ but the room was otherwise empty of artifacts. ${ }^{66}$ The entrance to the room

62 On the excavations of the relevant buildings (102, 113, 200, 300, 700, 800, 900, 910), see (Daviau 2003, chp. 6-9).

63 For figurines found in tombs and other sites in Ammon see (Clark 2017, pp. 379-81; Dabrowski 1997; Dabrowski 2000, 2009; Daviau 2002, pp. 51-73; Dornemann 1983, pp. 131-40; Herr 2014, pp. 400-7; Herr and Platt 2002, pp. 393-99; Platt 1989, p. 361; Platt and Herr 2002, pp. 166-69).

64 Texts from the biblical book of Jeremiah suggest the titles of some of these religious specialists amongst the peoples surrounding Israel (Jeremiah 27:9, 49:3), but it is impossible to know whether these titles represent categories native to the Ammonites (Hübner 1992, p. 276). Presumably, Ammonite religion conformed to the general trends in Levantine religion, and so some of these titles were relevant to the Ammonites. A non-provenanced seal (ØCAI, no. 1b) that is partially damaged contains the name $b d m l k m$, which some have suggested can be reconstructed as 'bdmlkm, "servant of Milkom," and thus may represent a priest. The reconstruction is not certain though, and even if it is, the name does not necessarily indicate profession.

65 Notably, the bench room at Kuntillet 'Ajrud (where plaster texts were also located on the walls), and Lachish cult room 49 (Zevit 2001, pp. 298-306).

66 (Ibrahim and van der Kooij 1991, pp. 20-21). 
also provided public access. ${ }^{67}$ The rest of the excavated areas appear to be rather modest storage and work areas, ${ }^{68}$ thus not giving any specific clues to the function of room EE335 except to say that it was not related to any items obviously sponsored by the state. The text discovered and reconstructed from the wall plaster that had fallen to the floor presents Balaam's oracular vision from 'El of what the Šaddayin gods were going to do, which apparently involves upheavals of the natural order of things. ${ }^{69}$ In addition to Balaam being a seer, Combination 1: line 11 mentions a priestess $(k h n h)$. The proximity of Deir 'Alla to Ammon suggests that these regular categories of religious specialists were probably also known in Ammon.

\section{Ethnic Affiliation and Coalitional Processes}

While there is precious little information from which we can reconstruct the role of religion in ethnic affiliation and coalitional processes among the Ammonites, there is little doubt that religion did play some role. It is a well-known part of ancient societies to have a state god that was understood to support the ruler, especially in military matters. For the Ammonites, this god was, in all likelihood Milkom (see above $\S 4.1$ ), a position that is also understood from the biblical author's perspective when listing Milkom as the "god of the Ammonites", along with "Astarte the goddess of the Sidonians" and "Chemosh the god of Moab" (1 Kings 11:33). Whether the Ammonites or other peoples of the Transjordan had groups within them that argued for exclusive devotion to the state god, as some did in Judah, cannot be determined at present. Nonetheless, as one salient aspect of individual and group identity, devotion to or acknowledgement of a particular deity - whether exclusive or not-is a likely aspect of Ammonite sociopolitical formation, even if only at the level of the ruling elite. What we do not know is whether the sons of Ammon were the only tribal or kinship group in Ammon, or if they were the ascendant or apical tribe for whom a coalition of tribes was known. If it is the latter, it is possible that part of what bound the group together was Milkom's place as the state god, who represented the political regime and aided the Ammonites in their military ventures.

\section{Conclusions}

This investigation of Ammonite religion reveals a typical specimen of Iron Age II Levantine religion. The non-physical realm was understood to be inhabited by gods, goddesses, and a variety of other non-human beings. The living had continued relations with dead ancestors through memory and ritual. Several types of cultic space have been discovered in Ammon. Unique among these is the probable temple to the moon-god at Rujm al-Kursi, which most likely reflects a local tradition of moon worship influenced by the iconography of the Mesopotamian moon-god Sîn. One distinguishing feature of Ammonite religion is the state god Milkom, whose name is probably an epithet for 'El, and who appears to be represented in a tradition of stone sculptures that have been found in the vicinity of Amman. In sum, the archaeological and textual material point to the lively place of religion among the Ammonites, and to a distinct—if not entirely unique—configuration of religious life.

Funding: This research received no external funding.

Acknowledgments: I would like to thank Avraham Faust for the invitation to contribute this article to this special issue on Archaeology and Israelite Religion. My thanks also to Walter Aufrecht for access to his forthcoming second edition of $A$ Corpus of Ammonite Inscriptions.

Conflicts of Interest: The author declares no conflicts of interest.

67 See the top plan in (Ibrahim and van der Kooij 1991, p. 19).

68 (Ibrahim and van der Kooij 1991, p. 18).

69 The editio princeps of the text is (Hoftijzer and van der Kooij 1976). For a recent presentation of the text and commentary on it, see (Ahituv 2008, pp. 434-65). 


\section{Abbreviations}

$C A I$

Aufrecht, Walter E. Forthcoming. A Corpus of Ammonite Inscriptions, 2nd ed. University Park: Eisenbrauns.

Eggler, Jürg, and Othmar Keel. 2006. Corpus der Siegel-Amulette aus Jordanien vom Neolithikum bis zur Perserzeit. Fribourg: Academic Press.

GKC Kautzsch, Emil, ed. 1910. Gesenius' Hebrew Grammar, 2nd ed. Translated by Arthur E. Cowley. Oxford: Clarendon.

Koehler, Ludwig, Walter Baumgartner, and Johann Jakob Stamm. 2001. The Hebrew and Aramaic

HALOT Lexicon of the Old Testament. Study ed. Translated and edited under the supervision of M. E. J. Richardason. Leiden: Brill.

\section{References}

Abou Assaf, Ali. 1980. Untersuchungen zur ammonitischen Rundbildkunst. Ugarit-Forschungen 12: 7-102. Aharoni, Yohanan. 1968. Arad: Its Inscriptions and Temple. Biblical Archaeologist 31: 2-32. [CrossRef] Ahituv, Shmuel. 2008. Echoes from the Past: Hebrew and Cognate Inscriptions from the Biblical Period. Jerusalem: Carta. Albertz, Rainer, and Rüdiger Schmitt. 2012. Family and Household Religion in Ancient Israel and the Levant. Winona Lake: Eisenbrauns.

'Amr, Abdel-Jalil. 1986. Ruğm al-Kursī. Archiv für Orientforschung 33: 211.

'Amr, Abdel-Jalil. 1990. Four Ammonite Sculptures from Jordan. Zeitschrift des Deutschen Palästina-Vereins 106: 114-18, Tafeln 7-8.

Aufrecht, Walter E. 1999. The Religion of the Ammonites. In Ancient Ammon. Edited by Burton MacDonald and Randall W. Younker. Leiden: Brill, pp. 152-62.

Avigad, Nahman, and Benjamin Sass. 1997. Corpus of West Semitic Stamp Seals. Jerusalem: The Israel Academy of Sciences and Humanities.

Barnett, Richard D. 1951. Four Sculptures from Amman. Annual of the Department of Antiquities of Jordan 1: 34-36. Becking, Bob. 1993. Baalis, the King of the Ammonites: An Epigraphical Note on Jeremiah 40:14. Journal of Semitic Studies 38: 15-24. [CrossRef]

Bernett, Monika, and Othmar Keel. 1998. Mond, Stier und Kult am Stadttor: Die Stele von Bethsaida (et-Tell). Freiburg: Universitätsverlag.

Black, Jeremy, and Anthony Green. 1992. Gods, Demons, and Symbols of Ancient Mesopotamia: An Illustrated Dictionary. Austin: University of Texas Press.

Bloch-Smith, Elizabeth. 1992. Judahite Burial Practices and Beliefs about the Dead. Sheffield: Sheffield Academic Press. Borger, Rykle. 1996. Beiträge zum Inschriftenwerk Assurbanipals. Wiesbaden: Harrassowitz.

Boyer, Pascal, and Brian Bergstrom. 2008. Evolutionary Perspectives on Relgion. Annual Review of Anthropology 37: 111-30. [CrossRef]

Burnett, Joel S. 2009. Iron Age Deities in Word, Image, and Name: Correlating Epigraphic, Iconographic, and Onomastic Evidence for the Ammonite God. Studies in the History and Archaeology of Jordan 10: 153-64.

Burnett, Joel S. 2016. Egyptianizing Elements in Ammonite Stone Statuary: The Atef Crown and Lotus. In Proceedings of the 9th International Congress on the Archaeology of the Ancient Near East. Edited by Rolf A. Stucky, Oskar Kaelin and Hans-Peter Mathys. Wiesbaden: Harrassowitz, pp. 57-69.

Clark, Douglas R. 2017. The Objects and Artifacts. In Madaba Plains Project 7: The 2000 Season at Tall al-'Umayri and Subsequent Studies. Edited by Larry G. Herr, Douglas R. Clark and Lawrence T. Geraty. Winona Lake: Eisenbrauns, pp. 365-432.

Cogan, Mordechai. 1974. Imperialism and Religion: Assyria, Judah and Israel in the Eighth and Seventh Centuries B.C.E.. Missoula: Society of Biblical Literature.

Cornell, Collin. 2015. A Moratorium on God Mergers? The Case of El and Milkom in the Ammonite Onomasticon. Ugarit-Forschungen 46: 49-99.

Cross, Frank M. 2003. Ammonite Ostraca from Tell Hisbān. In Leaves from an Epigrapher's Notebook: Collected Papers in Hebrew and West Semitic Palaeography and Epigraphy. Winona Lake: Eisenbrauns, pp. 70-99. 
Dabrowski, Boguslav. 1997. Clay Figurines from Tall al-'Umayri and Vicinity (The 1987 and 1989 Seasons). In Madaba Plains Project 3: The 1989 Season at Tell el-'Umeiri and Vicinity and Subsequent Studies. Edited by Larry G. Herr, Lawrence T. Geraty, Øystein S. LaBianca and Randall W. Younker. Berrein Springs: Andrews University Press, pp. 337-49.

Dabrowski, Boguslav. 2000. A Preliminary Report on Figurines and Clay Objects. In Madaba Plains Project 4: The 1992 Season at Tall al-'Umayri and Subsequent Studies. Edited by Larry G. Herr, Douglas R. Clark, Lawrence T. Geraty, Randall W. Younker and Øystein S. LaBianca. Berrein Springs: Andrews University Press, pp. 215-37.

Dabrowski, Boguslav. 2009. Terracotta Figurines from Tell Hesban and Vicinity. In Small Finds: Studies of Bone, Iron, Glass, Figurines, and Stone Objects from Tell Hesban and Vicinity. Edited by Paul J. Ray Jr. Berrein Springs: Andrews University Press, pp. 57-89.

Darby, Erin Danielle. 2014. Interpreting Judean Pillar Figurines: Gender and Empire in Judean Apotropaic Ritual. Tübingen: Mohr Siebeck.

Daviau, p. M. Michèle. 2001. Family Religion: Evidence for the Paraphernalia of the Domestic Cult. In The World of the Aramaeans II: Studies in History and Archaeology in Honour of Paul-Eugène Dion. Edited by p. M. Michèle Daviau, John W. Wevers and Michael Weigl. Sheffield: Sheffield Academic Press, pp. 199-229.

Daviau, p. M. Michèle. 2002. Excavations at Tall Jawa, Jordan, Volume II: The Iron Age Artefacts. Leiden: Brill.

Daviau, p. M. Michèle. 2003. Excavations at Tall Jawa, Jordan, Volume I: The Iron Age Town. Leiden: Brill.

Daviau, p. M. Michèle. 2008. Ceramic Architectural Models from Transjordan and the Syrian Tradition. In Proceedings of the 4th International Congress of the Archaeology of the Ancient Near East, 29 March-3 April 2004, Freie Universität Berlin. Volume 1: The Reconstruction of Environment: Natural Resources and Human Interrelations through Time. Art History: Visual Communication. Edited by Hartmut Kühne, Rainer M. Czichon and Florian Janoscha Kreppner. Wiesbaden: Harrassowitz, pp. 293-308.

Daviau, p. M. Michèle, and Paul-Eugène Dion. 1994. El, the God of the Ammonites? The Atef-Crowned Head from Tell Jawa, Jordan. Zeitschrift des Deutschen Palästina-Vereins 110: 158-67.

Daviau, p. M. Michèle, and Margreet Steiner. 2000. A Moabite Sanctuary at Khirbat al-Mudayna. Bulletin of the American Schools of Oriental Research 320: 1-21. [CrossRef]

Daviau, p. M. Michèle, and Margreet Steiner, eds. 2017. A Wayside Shrine in Northern Moab: Excavations in the Wadi ath-Thamad. Oxford: Oxbow Books.

Davis, Andrew R. 2013. Tel Dan in Its Northern Cultic Context. Atlanta: Society of Biblical Literature.

Dietrich, Manfred, and Martin A. Klopfenstein, eds. 1994. Ein Gott allein? JHWH-Verehrung und biblischer Monotheismus im Kontext der israelitischen und altorientalischen Religionsgeschichte. Freiburg: Universitätsverlag.

Dion, Paul-Eugène, and p. M. Michèle Daviau. 2000. An Inscribed Incense Altar of Iron Age II at Hirbet el-Mudēyine (Jordan). Zeitschrift des Deutschen Palästina-Vereins 116: 1-13.

Dornemann, Rudolph H. 1983. The Archaeology of the Transjordan in the Bronze and Iron Ages. Milwaukee: Milwaukee Public Museum.

Driver, Samuel Rolles. 1913. Notes on the Hebrew Text and the Topography of the Books of Samuel with an Introduction on Hebrew Palaeography and the Ancient Version and Facsimilies of Inscriptions and Maps, 2nd ed. Oxford: Clarendon Press.

Edelman, Diana V., ed. 1996. The Triumph of Elohim: From Yahwisms to Judaisms. Grand Rapids: Eerdmans.

Eggler, Jürg. 2009. Iconography of Animals in the Representation of the Divine (Palestine/Israel). In Iconography of Deities and Demons in the Ancient Near East. Edited by Jürg Eggler and Christoph Uehlinger. Available online: http:/ / www.religionswissenschaft.uzh.ch/idd/prepublications/e_idd_iconography_of_animals. pdf (accessed on 20 December 2018).

Elkins, Stefanie p. 2017. A Model Shrine from Tall al-'Umayri. In Madaba Plains Project 7: The 2000 Season at Tall al-'Umayri and Subsequent Studies. Edited by Larry G. Herr, Douglas R. Clark and Lawrence T. Geraty. Winona Lake: Eisenbrauns, pp. 433-46.

Elkowicz, Dominik. 2012. Tempel und Kultplätze der Philister und der Völker des Ostjordanlandes: Eine Untersuchung zur Bau- und zur Kultgeschichte während der Eisenzeit I-II. Münster: Ugarit-Verlag.

Elkowicz, Dominik. 2014. Der ammonitische Mondtempel von Ruğm el Kursi und die Tempel des "syrischen Tempeltypus". Biblische Notizen 160: 51-57.

Franken, Henk. J. 1969. Excavations at Tell Deir 'Allā I: Stratigraphical and Analytical Study of the Early Iron Age Pottery. Leiden: Brill. 
Gane, Roy E. 2008. Jalul Ostracon I. Bulletin of the American Schools of Oriental Research 351: 73-84. [CrossRef] Gnuse, Robert Karl. 1997. No Other Gods: Emergent Monotheism in Israel. Sheffield: Sheffield Academic Press.

Grayson, A. Kirk, and Jamie Novotny. 2012. The Royal Inscriptions of Sennarcherib, King of Assyria (704-681 BC), Part 1. Winona Lake: Eisenbrauns.

Green, Tamara M. 1992. The City of the Moon-God: Religious Traditions of Harran. Leiden: Brill.

Green, Douglas J. 2010. "I Undertook Great Works": The Ideology of Domestic Achievements in West Semitic Royal Inscriptions. Tübingen: Mohr Siebeck.

Haines, Richard C. 1971. Excavations in the Plain of Antioch II: The Structural Remains of the Later Phases: Chatal Hüyük, Tell al-Judaidah, and Tell Ta' yinat. Chicago: University of Chicago Press.

Harrison, Timothy P., and James F. Osborne. 2012. Building XVI and the Neo-Assyrian Sacred Precint at Tell Tayinat. Journal of Cuneiform Studies 64: 125-43. [CrossRef]

Hays, Christopher B. 2015. A Covenant with Death: Death in the Iron Age II and Its Rhetorical Uses in Proto-Isaiah. Grand Rapids: Eerdmans. First published 2011.

Heider, George C. 1999. Molech. In Dictionary of Deities and Demons in the Bible. Edited by Karel van der Toorn, Bob Becking and Pieter W. van der Horst. Leiden: Brill, pp. 581-85.

Herr, Larry G. 1985. The Servant of Baalis. The Biblical Archaeologist 48: 169-72. [CrossRef]

Herr, Larry G. 2014. The Objects. In Madaba Plains Project 6: The 1996 and 1998 Seasons at Tall al-'Umayri and Subsequent Studies. Edited by Larry G. Herr, Douglas R. Clark, Lawrence T. Geraty, Randall W. Younker and Øystein S. LaBianca. Berrein Springs: Andrews University Press, pp. 384-423.

Herr, Larry G., and Douglas R. Clark. 2009. From the Stone Age to the Middle Ages in Jordan: Digging up Tall al-'Umayri. Near Eastern Archaeology 72: 68-97. [CrossRef]

Herr, Larry G., and Mohammed Najjar. 2001. The Iron Age. In The Archaeology of Jordan. Edited by Burton MacDonald, Russell Adams and Piotr Bienkowski. Sheffield: Sheffield Academic Press, pp. 323-45.

Herr, Larry G., and Elizabeth E. Platt. 2002. The Objects from the 1989 Season. In Madaba Plains Project 5: The 1994 Season at Tall al-'Umayri and Subsequent Studies. Edited by Larry G. Herr, Douglas R. Clark, Lawrence T. Geraty, Randall W. Younker and Øystein S. LaBianca. Berrein Springs: Andrews University Press, pp. 358-99.

Herrmann, Wolfgang. 1999. Baal. In Dictionary of Deities and Demons in the Bible. Edited by Karel van der Toorn, Bob Becking and Pieter W. van der Horst. Leiden: Brill, pp. 132-39.

Herrmann, Virginia Rimmer, and J. David Schloen, eds. 2014. In Remembrance of Me: Feasting with the Dead in the Ancient Middle East. Chicago: The Oriental Institute of the University of Chicago.

Herzog, Ze'ev, Miriam Aharoni, Anson F. Rainey, and Shmuel Moshkovitz. 1984. The Israelite Fortress at Arad. Bulletin of the American Schools of Oriental Research 254: 1-34. [CrossRef]

Hoftijzer, Jean, and Gerritt van der Kooij. 1976. Aramaic Texts from Deir 'Alla. Leiden: Brill.

Hoftijzer, Jean, and Gerritt van der Kooij, eds. 1991. The Balaam Text from Deir 'Alla Re-evaluated: Proceedings of the International Symposium held at Leiden, 21-24 August 1989. Leiden: Brill.

Holladay, John S., Jr. 1987. Religion in Israel and Judah Under the Monarchy: An Explicitly Archaeological Approach. In Ancient Israelite Religion: Essays in Honor of Frank Moore Cross. Edited by Patrick D. Miller Jr., Paul D. Hanson and S. Dean McBride. Philadelphia: Fortress Press, pp. 249-99.

Holloway, Steven W. 1995. Harran: Cultic Geography in the Neo-Assyrian Empire and its Implications for Sennacherib's 'Letter to Hezekiah' in 2 Kings. In The Pitcher is Broken: Memorial Essays for Gösta W. Ahlström. Edited by Steven W. Holloway and Lowell K. Handy. Sheffield: Sheffield Academic Press, pp. 276-314.

Houtman, Cornelius. 1999. Queen of Heaven. In Dictionary of Deities and Demons in the Bible. Edited by Karel van der Toorn, Bob Becking and Pieter W. van der Horst. Leiden: Brill, pp. 678-80.

Hübner, Ulrich. 1992. Die Ammoniter: Untersuchungen zur Geschichte, Kultur und Religion eines transjordanischen Volkes im 1 Jahrtausend v. Chr. Wiesbaden: Otto Harrassowitz.

Hübner, Ulrich. 1993. Das ikonographische Repertoire der ammonitischen Siegel und seine Entwicklung. In Studies in the Iconography of Northwest Semitic Inscribed Seals: Proceedings of a Symposium Held in Fribourg on April 17-20, 1991. Edited by Benjamin Sass and Christoph Uehlinger. Fribourg: University Press Fribourg Switzerland, pp. 130-60.

Hübner, Ulrich. 2009. Der Mondtempel auf Rugm al-Kursi in der Ammonitis. In Israel zwischen den Mächten: Festschrift für Stefan Timm zum 65. Geburtstag. Edited by Michael Pietsch and Friedhelm Hartenstein. Münster: Ugarit-Verlag, pp. 145-53. 
Hübner, Ulrich. 2015. Noch einmal zum ammonitischen Mondtempel auf Ruğm al-Kursī. Die Welt des Orients 45: 193-99. [CrossRef]

Huffmon, Herbert B. 1999a. Brother. In Dictionary of Deities and Demons in the Bible. Edited by Karel van der Toorn, Bob Becking and Pieter W. van der Horst. Leiden: Brill, pp. 178-79.

Huffmon, Herbert B. 1999b. Father. In Dictionary of Deities and Demons in the Bible. Edited by Karel van der Toorn, Bob Becking and Pieter W. van der Horst. Leiden: Brill, pp. 326-28.

Humbert, Jean-Baptiste, and Fawzi Zayadine. 1992. Trois Campagnes de Fouilles à Ammân (1988-1991): Troisième Terrasse de la Citadelle (Mission Franco-Jordanienne). Revue Biblique 1992: 214-60.

Hundley, Michael B. 2013. Gods in Dwellings: Temples and Divine Presence in the Ancient Near East. Atlanta: Society of Biblical Literature.

Ibrahim, Moawiyah M. 1971. Two Ammonite Statuettes from Khirbet El-Hajjar. Annual of the Department of Antiquities of Jordan 16: 91-97.

Ibrahim, Moawiyah M., and Gerritt van der Kooij. 1991. The Archaeology of Deir 'Alla Phase IX. In The Balaam Text from Deir' Alla Re-Evaluated: Proceedings of the International Symposium Held at Leiden, 21-24 August 1989. Edited by J. Hoftijzer and Gerritt van der Kooij. Leiden: Brill, pp. 16-29.

Israel, Felice. 1990. Note Ammonite II: La religione degli Ammonite attraverso le fonti epigrafiche. Studi e materiali di storia delle religione $56: 307-37$.

Jackson, Kent p. 1983. Ammonite Personal Names in the Context of the West Semitic Onomasticon. In The Word of the Lord Shall Go Forth: Essays in Honor of David Noel Freedman in Celebration of His Sixtieth Birthday. Edited by Carol L. Meyers and Michael P. O'Connor. Winona Lake: Eisenbrauns, pp. 507-25.

Keel, Othmar. 1998. Goddesses and Trees, New Moon and Yahweh: Ancient Near Eastern Art and the Hebrew Bible. Sheffield: Sheffield Academic Press.

Keel, Othmar, and Christoph Uehlinger. 1998. Gods, Goddesses, and Images of God in Ancient Israel. Translated by Thomas H. Trapp. Minneapolis: Fortress Press.

Knoppers, Gary N. 2004. 1 Chronicles 10-29: A New Translation with Introduction and Commentary. New York: Doubleday.

Landes, George M. 1956. A History of the Ammonites. Ph.D. thesis, The Johns Hopkins University, Baltimore, MD, USA.

Leichty, Erle. 2011. The Royal Inscriptions of Esarhaddon, King of Assyria (680-669 BC). Winona Lake: Eisenbrauns.

Lelli, Fabrizio. 1999. Stars. In Dictionary of Deities and Demons in the Bible. Edited by Karel van der Toorn, Bob Becking and Pieter W. van der Horst. Leiden: Brill, pp. 809-15.

Lemaire, André. 1994. Déesses et dieux de Syrie-Palastine d'après les inscriptions (c. 1000-500 av. n. è.). In Ein Gott allein? JHWH-Verehrung und biblischer Monotheismus im Kontext der israelitischen und altorientalischen Religionsgeschicte. Edited by Walter Dietrich and Martin A. Klopfenstein. Fribourg: Fribourg University Press, pp. 127-58.

Lipiński, Edward. 1999. Shemesh. In Dictionary of Deities and Demons in the Bible. Edited by Karel van der Toorn, Bob Becking and Pieter W. van der Horst. Leiden: Brill, pp. 764-68.

Low, Russanne D. 1991. Field F: The Eastern Shelf. In Madaba Plains Project 2: The 1987 Season at Tell el-'Umeiri and Vicinity and Subsequent Studies. Edited by Larry G. Herr, Lawrence T. Geraty, Øystein S. LaBianca and Randall W. Younker. Berrein Springs: Andrews University Press, pp. 170-231.

Margueron, Jean-Claude. 1992. Nanna. In Book Nanna. Edited by David Noel Freedman. New York: Doubleday, vol. 6, p. 767.

Meshel, Ze'ev. 2012. Kuntillet Ajrud (Horvat Teman): An Iron Age II Religious Site on the Judah-Sinai Border. Jerusalem: Israel Exploration Society.

Millard, Alan. 1999. Nabû. In Dictionary of Deities and Demons in the Bible. Edited by Karel van der Toorn, Bob Becking and Pieter W. van der Horst. Leiden: Brill, pp. 607-10.

Momani, Ahmed, Anthi Koutsoukou, Glen L. Peterman, Peter Warnock, and Paul-Eugène Dion. 1997. The 1993 Excavations. In The Great Temple of Amman: The Excavations. Edited by Anthi Koutsoukou, Kenneth W. Russell, Mohammad Najjar and Ahmed Momani. Amman: American Center of Oriental Research, pp. 157-71.

Novák, Mirko. 2002. Zur Verbindung von Mondgott und Wettergott bei den Aramäern im 1. Jahrtausend v. Chr. Ugarit-Forschungen 33: 437-65. 
Ornan, Tallay. 1993. The Mesopotamian Influence on West Semitic Inscribed Seals: A Preference for the Depiction of Mortals. In Studies in the Iconography of Northwest Semitic Inscribed Seals: Proceedings of a symposium held in Fribourg on April 17-20, 1991. Edited by Benjamin Sass and Christoph Uehlinger. Freiburg: Universitätsverlag, pp. 52-73.

Ornan, Tallay. 2001. The Bull and its Two Masters: Moon and Storm Deities in Relation to the Bull in Ancient Near Eastern Art. Israel Exploration Journal 51: 1-26.

Paul, Shalom M. 1991. Amos: A Commentary on the Book of Amos. Minneapolis: Fortress Press.

Petit, Lucas, and Zeidan Kafafi. 2016. Beyond the River Jordan: A Late Iron Age Sanctuary at Tell Damiyah. Near Eastern Archaeology 79: 18-26. [CrossRef]

Pettinato, Giovanni. 2005. Inanna. In Book Inanna. Edited by Lindsay Jones. Detroit: Thomson Gale, vol. 6, pp. 4402-6.

Platt, Elizabeth E. 1989. 'Umeiri Objects. In Madaba Plains Project 1: The 1984 Season at Tell el-'Umeiri and Vicinity and Subsequent Studies. Edited by Lawrence T. Geraty, Larry G. Herr, Øystein S. LaBianca and Randall W. Younker. Berrein Springs: Andrews University Press, pp. 355-66.

Platt, Elizabeth E., and Larry G. Herr. 2002. The Objects. In Madaba Plains Project 5: The 1994 Season at Tall al-'Umayri and Subsequent Studies. Edited by Larry G. Herr, Douglas R. Clark, Lawrence T. Geraty, Randall W. Younker and Øystein S. LaBianca. Berrein Springs: Andrews University Press, pp. 156-70.

Porter, Benjamin W., and Alexis T. Boutin, eds. 2014. Remembering the Dead in the Ancient Near East: Recent Contributions from Bioarchaeology and Mortuary Archaeology. Boulder: University Press of Colorado.

Postgate, J. Nicholas. 1974. Taxation and Conscription in the Assyrian Empire. Rome: Biblical Institute Press.

Prag, Kay. 1987. Decorative Architecture in Ammon, Moab, and Judah. Levant 19: 121-27. [CrossRef]

Puech, Emile. 1977. Milkom, le dieu ammonite, en Amos I 15. Vetus Testamentum 27: 117-25. [CrossRef]

Puech, Emile. 1999. Milcom. In Dictionary of Deities and Demons in the Bible. Edited by K. van der Toorn, B. Becking and p. W. van der Horst. Leiden: Brill, pp. 575-76.

Rollston, Christopher A. 2004. Non-Provenanced Epigraphs II: The Status of Non-Provenanced Epigraphs within the Broader Corpus of Northwest Semitic. Maarav 11: 57-79.

Rollston, Christopher A. 2010. Writing and Literacy in the World of Ancient Israel: Epigraphic Evidence from the Iron Age. Atlanta: Society of Biblical Literature.

Routledge, Bruce. 2004. Moab in the Iron Age: Hegemony, Polity, Archaeology. Philadelphia: University of Pennsylvania Press.

Schmidt, Brian B. 1996. Israel's Beneficent Dead: Ancestor Cult and Necromancy in Ancient Israelite Religion and Tradition, pbk. ed. Winona Lake: Eisenbrauns.

Schmidt, Brian B. 1999. Moon. In Dictionary of Deities and Demons in the Bible. Edited by Karel van der Toorn, Bob Becking and Pieter W. van der Horst. Leiden: Brill, pp. 585-93.

Seow, Choon-Leong. 1999. Am. In Dictionary of Deities and Demons in the Bible. Edited by Karel van der Toorn, Bob Becking and Pieter W. van der Horst. Leiden: Brill, pp. 24-26.

Smith, Mark S. 2001. The Origins of Biblical Monotheism: Israel's Polytheistic Background and the Ugaritic Texts. Oxford: Oxford University Press.

Smith, Mark S. 2002. The Early History of God: Yahweh and the Other Deities in Ancient Israel. Grand Rapids: Eerdmans.

Staubli, Thomas. 2003. Sin von Harran und seine Verbreitung im Westen. In Werbung für die Götter. Heilsbringer aus 4000 Jahren. Edited by Thomas Staubli. Fribourg: Academic Press, pp. 65-89.

Stavrakopoulou, Francesca. 2010. Land of our Fathers: The Roles of Ancestor Veneration in Biblical Land Claims. New York: T \& T Clark.

Tadmor, Hayim, and Shigeo Yamada. 2011. The Royal Inscriptions of Tiglath-Pileser II (744-727 BC) and Shalmaneser $V$ (726-722 BC), Kings of Assyria. Winona Lake: Eisenbrauns.

Te Velde, Herman. 1999. Bes. In Dictionary of Deities and Demons in the Bible. Edited by Karel van der Toorn, Bob Becking and Pieter W. van der Horst. Leiden: Brill, p. 173.

Theuer, Gabriele. 2000. Der Mondgott in den Religionen Syrien-Palästinas: Unter besonderer Berücksichtigung von KTU 1.24. Freiburg: Universitätsverlag.

Tigay, Jeffrey H. 1987. Israelite Religion: The Onomastic and Epigraphic Evidence. In Ancient Israelite Religion: Essays in Honor of Frank Moore Cross. Edited by Patrick D. Miller Jr., Paul D. Hanson and Samuel Dean McBride. Philadelphia: Fortress Press, pp. 157-94. 
Tyson, Craig W. 2014. The Ammonites: Elites, Empires, and Sociopolitical Change (1000-500 BCE). London: Bloomsbury T \& T Clark.

Van der Toorn, Karel. 1996a. Ancestors and Anthroponyms: Kinship Terms as Theophoric Elements in Hebrew Names. Zeitschrift für die Alttestamentliche Wissenschaft 108: 1-11. [CrossRef]

Van der Toorn, Karel. 1996b. Family Religion in Babylonia, Syria and Israel: Continuity and Change in the Forms of Religious Life. Leiden: Brill.

Werse, Nicholas R. 2018. Of Gods and Kings: The Case for Reading "Milcom" in Zephaniah 1:5b $\beta$. Vetus Testamentum 68: 505-13. [CrossRef]

Yassine, Khair. 1984. Tell el Mazar I: Cemetery A. Amman: University of Amman Press.

Yassine, Khair. 1999. Burial Customs and Practices in Ancient Ammon. In Ancient Ammon. Edited by Burton MacDonald and Randall W. Younker. Leiden: Brill, pp. 137-51.

Zayadine, Fawzi. 1973. Recent Excavations on the Citadel of Amman. Annual of the Department of Antiquities of Jordan 18: 17-35.

Zayadine, Fawzi. 1991. Sculpture in Ancient Jordan. In Treasures from an Ancient Land: The Art of Jordan. Edited by Piotr Bienkowski. Phoenix Mill: Alan Suttone, pp. 31-61.

Zayadine, Fawzi, Jean-Baptiste Humbert, and Najjar Mohammed. 1989. The 1988 Excavations of the Citadel of Amman, Lower Terrace, Area A. Annual of the Department of Antiquities of Jordan 33: 357-63.

Zevit, Ziony. 2001. The Religions of Ancient Israel: A Synthesis of Parallactic Approaches. London: Continuum.

(C) 2019 by the author. Licensee MDPI, Basel, Switzerland. This article is an open access article distributed under the terms and conditions of the Creative Commons Attribution (CC BY) license (http://creativecommons.org/licenses/by/4.0/). 